\title{
Severe Deep Moist Convective Storms: Forecasting and Mitigation
}

\author{
David L. Arnold* \\ Department of Geography, Frostburg State University
}

\begin{abstract}
Small-scale $(2-20 \mathrm{~km})$ circulations, termed 'severe deep moist convective storms', account for a disproportionate share of the world's insured weather-related losses. Spatial frequency maximums of severe convective events occur in South Africa, India, Mexico, the Caucasus, and Great Plains/Prairies region of North America, where the maximum tornado frequency occurs east of the Rocky Mountains. Interest in forecasting severe deep moist convective systems, especially those that produce tornadoes, dates to 1884 when tornado alerts were first provided in the central United States. Modern thunderstorm and tornado forecasting relies on technology and theory, but in the post-World War II era interest in forecasting has also been driven by public pressure. The forecasting process begins with a diagnostic analysis, in which the forecaster considers the potential of the atmospheric environment to produce severe convective storms (which requires knowledge of the evolving kinematic and thermodynamic fields, and the character of the land surface over which the storms will pass), and the likely character of the storms that may develop. Improvements in forecasting will likely depend on technological advancements, such as the development of phased-array radar systems and finer resolution numerical weather prediction models. Once initiated, the evolution of deep convective storms is monitored by satellite and radar. Mitigation of the hazards posed by severe deep moist convective storms is a threestep process, involving preparedness, response, and recovery. Preparedness implies that risks have been identified and organizations and individuals are familiar with a response plan. Response necessitates that potential events are identified before they occur and the developing threat is communicated to the public. Recovery is a function of the awareness of local, regional, and even national governments to the character and magnitude of potential events in specific locations, and whether or not long-term operational plans are in place at the time of disasters.
\end{abstract}

\section{Introduction}

Globally, atmospheric and hydrologic hazards accounted for an average annual death toll of approximately 56,000 people from 1992-2001 (WMO 2004), with economic costs exceeding US\$1.4 trillion (\$2004) for the period 1980-2004 (Mills 2005). Perhaps surprisingly, Mills (2005) 
found that the majority of insured weather-related losses (approximately 60\%) were associated with small-scale events as opposed to the more conspicuous larger-scale disasters that tend to dominate network news stories.

The most powerful small-scale atmospheric storms (from an energy-density perspective) are 'convective' in nature. These systems, referred to as deep moist convective (DMC) storms, represent local-scale $(2-20 \mathrm{~km})$ circulations driven by conversions of potential buoyant energy (PBE) (within conditionally unstable environments) to the kinetic energy of updraft accelerations. This 'release' of PBE, a process termed convective initiation, often requires a dynamically forced triggering mechanism. These forcing mechanisms are necessary because most convectively favorable environments are characterized by levels of free convection (LFC; height to which air must ascent before free convection occurs) that are elevated above the earth's surface. Because a temperature inversion (commonly referred to as a cap or lid) often exists below the LFC, triggering mechanisms must be capable of generating enough vertical motion to overcome the convective inhibition that exists within the inversion for the rising air to reach the LFC. In most cases, surface heating is not sufficient to overcome the convective inhibition, and dynamical forcing of vertical motion is required. These forcing mechanisms typically exist in response to low-level mass and moisture convergence associated with atmospheric and topographical boundaries, baroclinic circulations that develop within low-level temperature gradients, and the advection of larger-scale lift associated with upper-level shortwaves and jet stream circulations. In some cases, the conditionally unstable air is able to flow underneath the capping inversion over large enough distances to reach an area where the inversion no longer exists, and DMC storms are initiated. This process is termed underrunning (Farrell and Carlson 1989).

It is important to note that any DMC storm is an evolutionary process that exhibits a distinct lifecycle. Because these circulations represent a response to atmospheric disequilibrium (in this case conditional instability), it is important to understand that their role is to return the environment to a more stable condition. For example, as the environment begins to return to a more balanced state, the DMC updraft will weaken, which typically signals the initial stages of storm dissipation. It should be recognized, however, that the peak in DMC storm power at the surface usually follows updraft deceleration by several minutes, as the 'collapse' (lowering to the earth's surface) of the elevated precipitation core (dense collection of hail stones and hydrometeors) is typically accompanied by strong surges of low-level outflow air.

Severe DMC storms, capable of high-intensity rainfall $(\geq 7.6 \mathrm{~mm} / \mathrm{hr}$ ), large hail $(\geq 5 \mathrm{~cm})$, severe downdraft winds $(\geq 33 \mathrm{~m} / \mathrm{sec})$ and strong tornadoes, typically involve local-scale energy conversions of $1000-2000 \mathrm{j} / \mathrm{kg}$ resulting in very powerful vertical circulations. The upward accelerations responsible for DMC storm 'power' (often estimated by storm top altitudes), in combination with the height of the freezing level, determines precipitation efficiency and the likelihood and size of hail that reaches the earth's surface. 
On the other hand, the magnitude of downward accelerations play a significant role in determining strength of surface outflow winds in the downdraft region of these storms. It is hail, severe downdraft winds, and high-intensity rainfall that are typically associated with the greatest economic losses from DMC storms.

Successfully mitigating the impacts of atmospheric and hydrologic hazards requires a three-stage process involving preparedness, response, and recovery. To a significant extent, the ability to both prepare and respond is a function of accurate risk assessments on a variety of time and space scales. The real difficulty in providing accurate risk assessment, particularly in the form of timely warnings, lies in the direct relationship between the spatial and temporal scales of severe DMC storms. In other words, it is the very short lifecycles (generally minutes) of local-scale thunderstorms that make them so difficult to forecast.

While individual DMC circulations exist on rather small time and space scales, most do not progress through their lifecycles in steady-state fashion. In general, low-level outflow produced in the downdraft region enhances surface convergence within the vicinity of single-cell circulations (each cell consisting of a single updraft and downdraft) initiating new convective circulations along their periphery. Because these new circulations develop at different points in time, a series of DMC cells typically exist in different lifecycle stages simultaneously. Eventually, the discrete DMC cells may merge into an organized cluster of circulations commonly referred to as a mesoscale convective system (MCS) (Hane 1986; Zipser 1982).

In reality, it is rather rare to observe a single-isolated DMC storm, as most tend to quickly evolve toward MCS morphology (line or cluster). For this reason, the term 'thunderstorm' is often used in reference to a series of DMC convective circulation cells (i.e. an MCS), as opposed to a single-isolated updraft-downdraft couplet.

Globally, thunderstorms are most common (annual number of thunderstorm 'days') in the tropics, particularly south of the equator in South America, Africa, and northern Australia (Court and Griffiths 1985). However, the greatest frequencies of surface-observed hail, a characteristic of the most powerful thunderstorms, are found in South Africa/Lesotho, northwest India, the Sierra Madre Occidental of Mexico, the Caucasus of Eurasia, and the Great Plains/Prairies of the United States and Canada. Tornado frequency, an important component of the global severe thunderstorm climatology, is biased to a certain extent toward coastal areas due to their common association with tropical cyclones. For example, in 1967 Hurricane Beulah produced 115 documented tornadoes in Texas alone (Orton 1970).

While the central portions of the United States and Canada east of the Rocky Mountains represent the region of largest non-tropical cyclonegenerated tornado frequency, the UK and much of northwestern Europe appear to experience a secondary spatial maximum. Japan, new Zealand, and Australia also observe relatively large tornado frequencies, although a 
significant proportion are likely generated in response to large low-level vertical speed and directional shear environments produced by approaching tropical cyclones.

While North America does not represent the only global region of significant non-tropical tornado frequency, the combination of hail and non-tropical cyclone tornado frequencies suggests that this region likely represents the 'severe DMC capital of the world'. As a result, given the agricultural significance and population centers of this region, much attention has been given to forecasting severe thunderstorms within the central United States since the early 1950s. In support of this objective, the US Air Force and National Weather Service have been involved with documenting severe thunderstorm events for more than 50 years. As a result, Brooks (2006) considers the US record of severe thunderstorm events to represent the 'gold standard' for the world, with most other regions suffering significant under-reporting problems.

Although severe thunderstorm research has certainly not been limited to the United States, the greatest volume of work related to forecasting for purposes of advanced warning has been carried out in this region. As a result, severe thunderstorm literature is dominated by either US researchers, or a focus on North America's 'Tornado Alley'.

As time has progressed, research objectives have shifted from a focus on larger-scale regional environments supportive of severe thunderstorms to those of local-scale nowcasting on the order of hours and minutes. While the objective of improving warning lead times for severe DMC storms is directly tied to local-scale nowcasting, it has only been within the last 20 years that technological advancements in high-resolution satellite and radar remote sensing systems has made this approach possible (Arnold 2005).

\section{Early Forecasting}

\subsection{PRE-WORLD WAR II ERA}

With westward population expansion in North America during the mid-19th century came more frequent observations of severe thunderstorms and tornadoes as early settlers traversed 'Tornado Alley' (a region roughly including the states of Texas, Oklahoma, Kansas, Nebraska, Colorado, and South Dakota). The establishment of military outposts by the US Army in remote locations of the western Plains resulted in further observations, and by 1870 the US Army Signal Corps, mandated by the US federal government to establish a national weather service, began the process of documenting occurrences of severe thunderstorms. A significant step was taken to meet this objective in the middle 1880s when Sergeant John P. Finley of the US Army organized a group of approximately 2000 weather observers for the purpose of assessing severe thunderstorm environments (Galway 1985). As a result, Finley began to issue the world's first 'tornado alerts' in 1884. 
Despite efforts to provide early warning of possible tornadoes, the US federal government banned use of the term 'tornado' in weather forecasts in the late 1880s in fear of initiating panic among the general population, although there has been some suggestion that personal conflicts between Finley and his superiors might have been involved (Bradford 1999). While some work continued in the area of severe DMC environment recognition until the ban was lifted in 1938, focus on a more aggressive approach to severe thunderstorm forecasting did not begin until the late 1940s when the first successful tornado forecast was made by the US Air Force meteorologists E. J. Fawbush and R. C. Miller on March 25, 1948, at Tinker Air Force Base in central Oklahoma (Miller and Crisp 1999).

\subsection{POST-WORLD WAR II ERA}

The resurgence of interest in forecasting severe thunderstorms (e.g. Lloyd 1942) that resulted from a lift on the 'tornado' term ban in official US Weather Bureau (USWB) forecasts, in combination with recognition of the turbulence hazard to aviation operations during World War II, stimulated a new era of severe thunderstorm research during the 1940s and 1950s. While the theoretical underpinnings of DMC were well established over the first half of the 20th century (Benard 1901; Brunt 1937; Chandra 1938; Mal and Rao 1945; Phillips and Walker 1932), it was the advent of weather surveillance radar in 1941 (Ligda 1951) that provided the first true mesoscale analysis tool that made field investigation programs viable.

Thunderstorm turbulence was becoming a significant threat to the aviation sector during World War II as pilots could not always deviate their flight paths around DMC storms. The need for improved understanding of the dynamics of these systems led to a series of proposals by Dr. C. E. Buell, chief meteorologist of American Airlines, with support from the Civil Aeronautics Board, Air Transport Association, and USWB. These efforts culminated in design of the 'Thunderstorm Project' headed by Dr. Horace R. Byers of the University of Chicago (Byers and Braham 1949). This project was carried out in two phases, one at Ocala, Florida, in 1946, and a second at Wilmington, Ohio, in 1947. These projects served as the first observational field studies for purposes of documenting characteristics and processes of DMC storms. Results of the project included a conceptual model of the classic 'thunderstorm lifecycle' (cumulus, mature, and dissipating stages), along with improved understanding of thunderstorm structure and circulation (including turbulence), electrical fields within DMC storms, radar signatures, environmental wind fields, topographical and geographical effects, and the general impacts of thunderstorms on aircraft.

Even with lifting of the 'tornado' term ban, the USWB purposefully avoided tornado forecasts through 1952, even after the USWB Severe Weather Unit had been established in Washington, DC (later renamed the Severe Local Storms (SELS) Unit and moved to Kansas City, Missouri). 
With the well-publicized successes of the US Air Force's (USAF) Fawbush and Miller, and establishment of the USAF Air Weather Service Severe Weather Warning Center in 1951, public pressure mounted on the USWB to issue tornado outlooks (Miller and Crisp 1999). By 1953, the primary objectives of SELS (renamed the National Severe Storms Forecast Center in 1966, then relocated to Norman, Oklahoma, and named the Storm Prediction Center in 1995) was to issue tornado and severe thunderstorm watches; although the dissemination of daily 'convective outlooks' that highlighted regions in which severe weather might occur well ahead of watch issuance, was perhaps one of their most valuable products (Ostby 1999). To this day, much of what has been gained in support of the early warning of severe thunderstorm and tornadoes has come from the work of the SELS/Storm Prediction Center and the National Severe Storms Laboratory (NSSL) located in Norman, Oklahoma.

During the same period in which the US government was embarking on tornado outlooks, research was being carried out in Europe to greatly improve newly developed weather surveillance radar. Doppler radar, one of the most important tools used to detect substorm-scale structure and circulation, was first employed in 1953 at the Cavendish Laboratory, Cambridge, England (Barratt and Browne 1953). Doppler radar research and development continued through the 1950s with significant advances made by Lhermitte in France. By the 1960s, the Sperry Rand Corporation, under contract with the US Air Force, employed the services of Lhermitte and the NSSL began research toward development of an operational Doppler weather radar network. Similarly, the US Federal Aviation Administration was also developing Doppler radar for aviation operations, and together with the NSSL, the Joint Doppler Operational Project was initiated in 1976 to determine the potential for a new Doppler radar network (Joint Doppler Operational Project Staff 1979). Although several problems were encountered in the ultimate production of this system, the US new National Weather Service Weather Surveillance Radar, with Doppler components, was released for field testing in the late 1980s. By the early to middle 1990s, the Weather Surveillance Radar (WSR-88D) network had become operational nationwide. Similar networks have since been developed, or are in the process of development globally, although nowhere is the network of Doppler radar stations as dense as the central and eastern United States.

Following initial launch of experimental polar orbiting weather satellites in the late 1950s and early 1960s, significant advancement was made on the development of operational geostationary satellite systems. Today, global geostationary satellite coverage is made possible by Meteosat (operated by the European Organization for the Exploitation of Meteorological Satellites) that covers the Eastern Atlantic, Europe, and Africa, Geostationary Operational Environmental Satellites (GOES)-East (operated by the US National Environmental Satellite, Data, and Information Service; NESDIS) that samples the Western Atlantic, and North and South America, GOES-West 
(NESDIS) that observes Western North America and the Eastern Pacific, GMS (Geostationary Meteorological Satellite operated by the Japan Meteorological Agency) that views the Western Pacific, Japan, and Australia, Fengyun-2 (Shanghai Academy of Space Flight Technology and China Academy of Space Technology) that covers China and the Indian Ocean, and INSAT (Indian Space Research Organization) that observes Asia, East Africa, and the Indian Ocean.

While important DMC research contributions continue to be made from polar-orbiting satellite programs (Scofield and Purdom 1986), it was advent of the geostationary satellites that allowed high-frequency sampling of mesoscale processes from space possible for the first time. Initially, it was the superior resolution of visible imagery that allowed monitoring of convective environments and storm structure from geostationary platforms during daylight hours, but as spatial resolution improved in the infrared channels, valuable information regarding local-scale convective processes has become available (Menzel and Purdom 1994).

Early use of satellite data involved the identification of convective triggers such as mesohighs and thunderstorm outflow boundaries (Purdom 1972), atmospheric and topographic boundaries, and boundary intersections (Purdom 1976), thunderstorm growth rates associated with the occurrence of severe convective weather (Adler and Fenn 1978), and satellite signatures of severe hail (Reynolds 1980) and tornadic storms (Adler et al. 1980, 1985; Adler and Fenn 1981; McCann 1983). In recent years, the focus has turned more toward case studies of variability in DMC storm environment and structural evolution (e.g. LaPenta et al. 2005; Maddox and Doswell 1982; Przybylinski 1995; Uccellini 1975; Weaver et al. 1994).

\section{Modern-Day Forecasting}

\subsection{DIAGNOSTIC ANALYSIS}

Any weather forecasting process, regardless of scale or circulation type, begins with a diagnosis (Doswell 1986; Doswell and Maddox 1986). The purpose of a diagnostic analysis is to establish a starting point from which forecasters are able to extrapolate environmental evolution into the future. In the case of severe DMC, forecasters work to identify pre-storm environments that may be supportive of an array of possible storm types for specific locations and timeframes. As a result, familiarity with DMC processes in combination with a wide range of four-dimensional conceptual models is necessary for successful DMC forecasting. This process is typically carried out from a spatially nested domain perspective; that is, beginning with the larger synoptic scale $(>2000 \mathrm{~km}$ in length), then working down through the subsynoptic meso- $\alpha(200-2000 \mathrm{~km})$, meso- $\beta(20-200 \mathrm{~km})$, and meso- $\gamma$ $(2-20 \mathrm{~km})$ scales (Orlanski 1975). The meso- $\gamma$ scale is referred to as the 'local' or 'storm' scale that is the focus of the near real-time nowcasting in support 


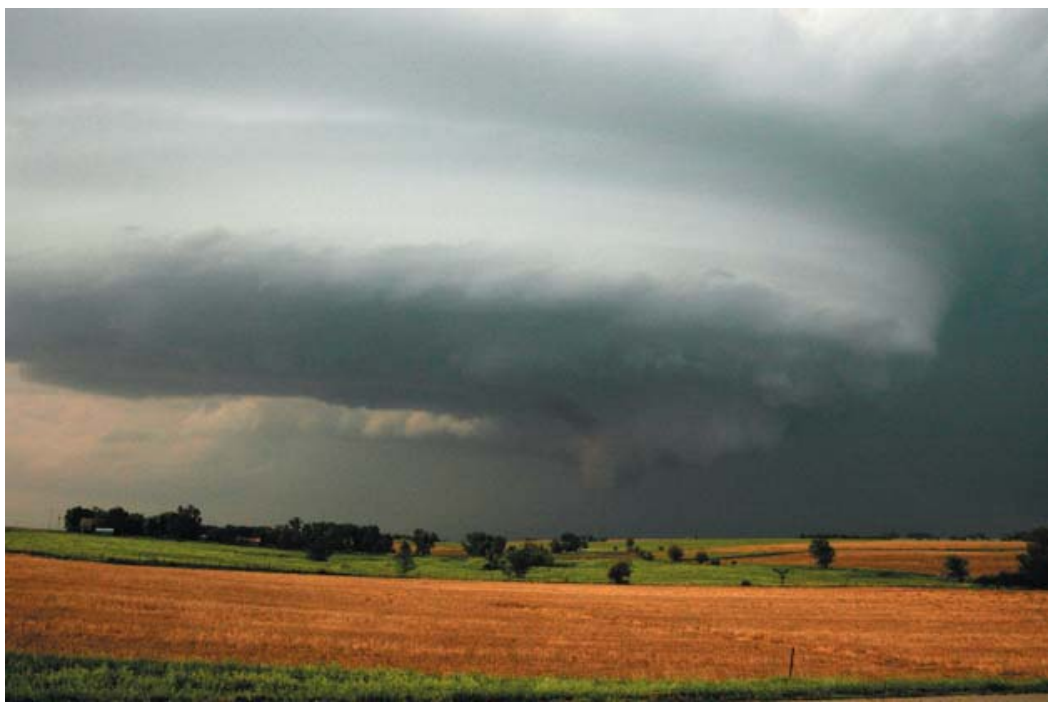

Fig. 1. Supercell thunderstorm near Republic, Kansas, May 22, 2004 (photo by Fred Kissinger).

of warning issuance. Given the direct relationship between the spatial and temporal components of atmospheric circulations (Ayra 1988; Fujita 1981; Pielke 2002; Stull 1988; Vinnichenko 1970), the synoptic-scale analysis is typically carried out $72-12 \mathrm{hr}$ ahead of DMC initiation, with subsynopticscale analyses undertaken from $12 \mathrm{hr}$ ahead, to within just minutes of initiation.

Until the modern era began with the advent of Doppler radar, highresolution satellite imagery, and meso-scale surface observing networks, much of the forecasting attention was restricted to the synoptic and meso- $\alpha$ scales with primary emphasis on pattern recognition. While the necessary atmospheric conditions for DMC had been well understood because the work of Benard (1901) in the very early 20th century, the ability to assess DMC 'ingredients' was driven by simple synoptic- and meso- $\alpha$-scale rules based on hydrostatic instability (condition supportive of free convection) and vertical wind shear (rapid change in the character of the wind with height). It was not until the early 1960s that the character and processes of supercell thunderstorms, those DMC storms most capable of producing significant tornadoes, were well understood (Figure 1).

\subsection{SYNOPTIC-SCALE DMC PROCESSES AND ENVIRONMENTS}

The great majority of severe DMC storms occur under synoptic-scale circulation patterns favoring low-level moist air, a mid-level dry intrusion and lifting mechanism capable of initiating DMC (Carlson and Ludlam 1968; Fawbush and Miller 1953; Johns and Doswell 1992). Although considerable variation is observed in this general pattern, the 'classic' severe DMC 


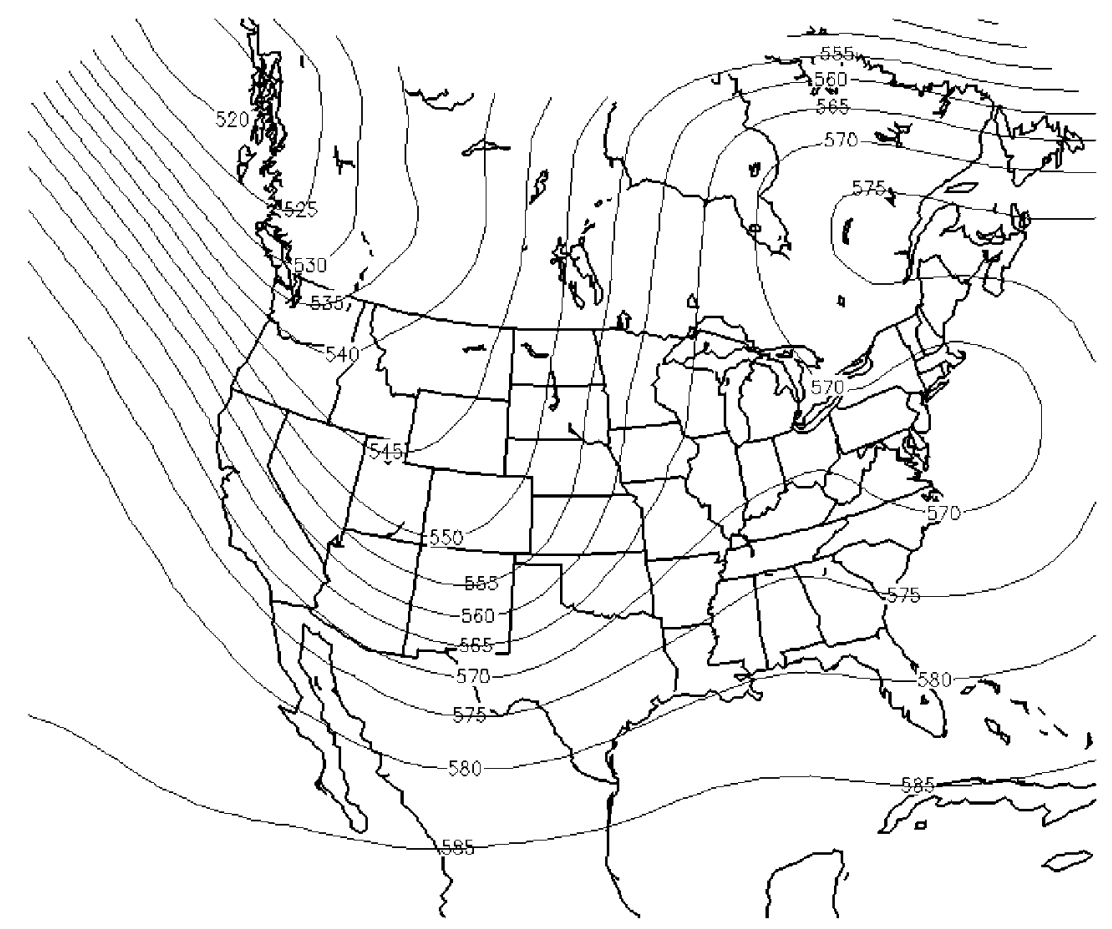

Fig. 2. Classic severe DMC synoptic-scale $500 \mathrm{hPa}$ geopotential height pattern observed May 3, 1999. Seventy tornadoes occurred in Oklahoma and Kansas during the afternoon and evening hours with 40 deaths and US\$1.2 billion in damage (NOAA, National Centers for Environmental Analysis Reanalysis Data).

environment can be described by the coexistence of three airstreams: (i) strong upper tropospheric 'jet stream' winds with a large westerly component, (ii) southwesterly flow at the mid-levels, and (iii) southerly flow within the planetary boundary layer (PBL) (Fawbush et al. 1951) (Figures 2-4).

At the synoptic and meso- $\beta$ scales, upper tropospheric jet streams and the approach of mid- and upper-level shortwaves contribute to the vertical motion necessary to initiate DMC in response to geostrophic circulations (the result of an imbalance of horizontal forces) necessary to regain balance in the wind fields (balance regained by the production of vertical motion fields) (Beebe and Bates 1955; Lee and Galway 1956, 1958). Specifically, Bjerknes and Holmboe (1944) and Riehl (1952) showed that speed maxima produce a quadrant-like pattern of upper-level divergence (left-front jet exit and right-rear jet entrance quadrants) and convergence (right-front jet exit and left-rear jet entrance quadrants) at the jet stream level in response to a passing wind speed maximum. Because upward vertical motion occurs under areas of upper divergence, and subsidence under regions of upper-level 


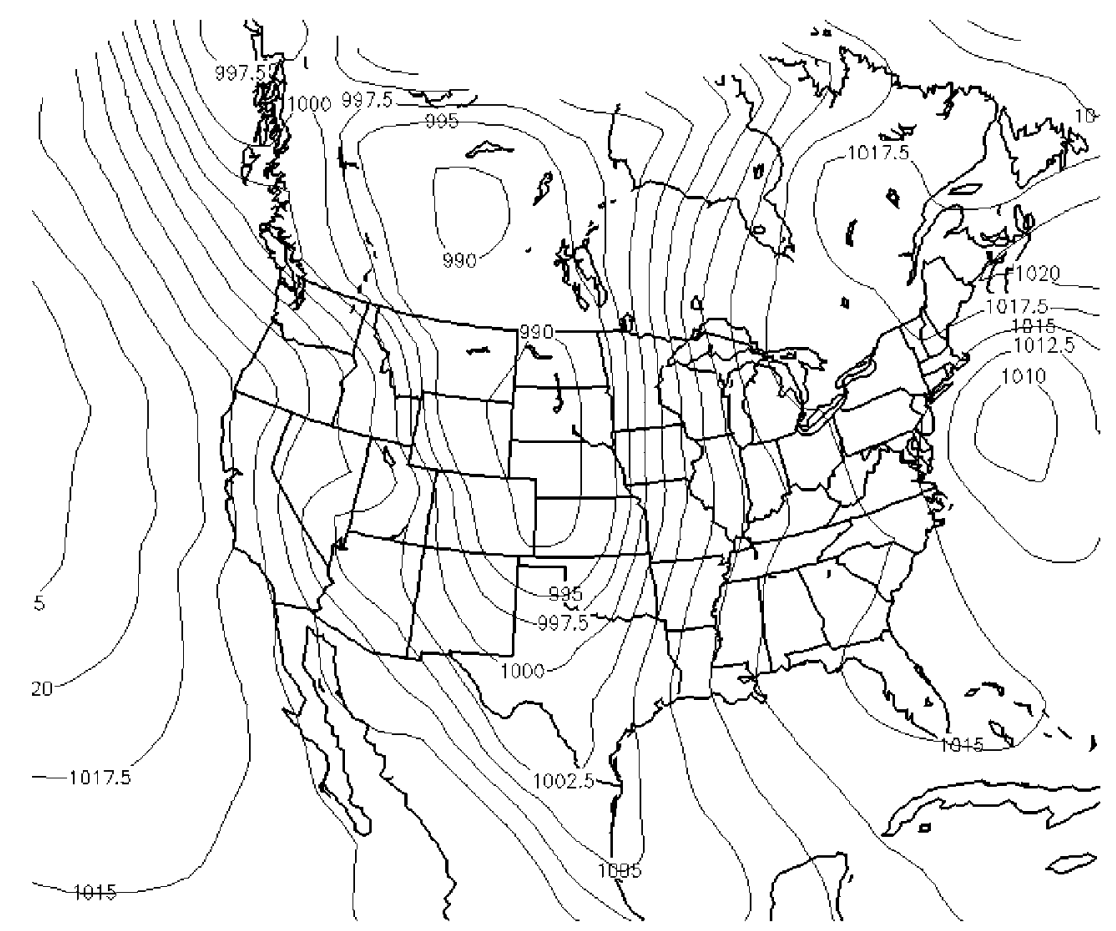

Fig. 3. Classic severe DMC synoptic-scale sea-level pressure pattern observed May 3, 1999.

convergence, this results in the left exit and right entrance regions of a jet streams speed maxima as favorable areas for DMC.

Moore et al. (1990), however, suggest the quadrant pattern applies only to geometrically 'straight' jets, and that curved jets exhibit only a single divergence/convergence dipole. In the case of cyclonically curving jets, convergence (surface divergence) is found in the entrance sector just to the north of the jet axis, while divergence (convergence at the surface) is located just north of the jet in the exit sector. For an anticyclonically curving jet, upperlevel divergence is located just south of the jet within the entrance sector, while upper-level convergence is situated in the exit sector just to the south of the jet core.

Areas of upper-level divergence typically located downstream of a trough axis also represent highly favorable regions for severe DMC development (Barnes and Newton 1986). Upper-level divergence that results from approaching shortwaves is most commonly recognized (although not always correctly - see Doswell 1986) through the identification of positive vorticity advection (Harman 1971) on 500 hectopascal (hPa) level absolute vorticity maps (Chaston 2002). Positive vorticity advection involves the transport of positive absolute vorticity, or cyclonic spin (contributions 


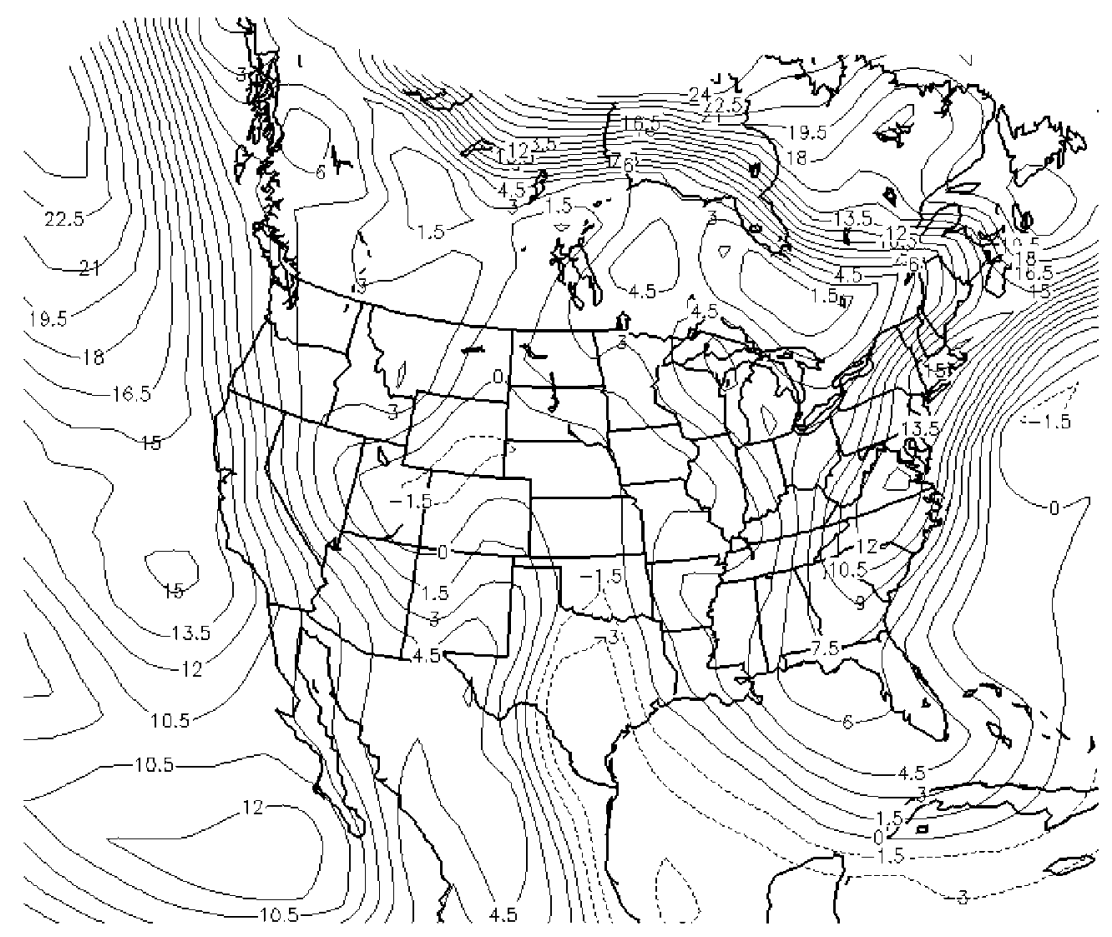

Fig. 4. Lifted Index values (solid lines = positive values and hydrostatic stability; broken lines negative values and instability) for May 3, 1999.

from earth's cyclonic rotation, known as earth vorticity, and cyclonic rotation of individual particles downstream from shortwave trough and jet stream axes, termed relative vorticity), by the horizontal wind; a processes known as geostrophic advection. As the particles move out and away from the upperlevel trough axis, positive vorticity decreases. According to the quasigeostrophic vorticity equation (Holton 1992) decreasing positive vorticity is associated with increasing divergence aloft and increasing synoptic-scale vertical motion. Because the atmosphere behaves as a nearly incompressible fluid on the synoptic scale, convergence and upward vertical motion occurs in the lower levels of the troposphere underneath regions of upper-level divergence due to the conservation of mass; a process commonly referred to as Dines Compensation. It is important to note that divergence can be significantly enhanced just downwind of the merger between a cyclonically curving polar jet found within an upper-level trough and anticyclonically curving subtropical jet (Uccellini and Kocin 1987), and that many of the severe thunderstorm 'outbreaks' that have occurred are found within these difluent regions.

Synoptic-scale circulation patterns within the PBL also play an important role in the development of the pre-storm environment. For example, in 
North America low-level warm air advection from the Gulf of Mexico furnishes the large amount of latent instability (indicated by large values of PBE) necessary to fuel deep convective storms. In cases where the jet stream is weak and synoptic-scale vorticity advection small, low-level warm air advection can provide sufficient moisture and mass convergence to generate severe DMC (Maddox and Doswell 1982; Moller 1980; Tegtmeier 1974).

Moisture and mass convergence can be greatly enhanced within the PBL through development of a low-level jet (LLJ). LLJs, with wind speeds of $18-33 \mathrm{~m} / \mathrm{sec}$, are typically found at heights between 600 and $2000 \mathrm{~m}$ above the earth's surface. They are a common component of migrating extratropical cyclones, but also form in response to the decoupling of mid-level wind flow from the PBL at night in response to a strengthening nocturnal radiation inversion (Blackadar 1957; Bonner 1966, 1968; Holton 1967; Pitchford and London 1962; Wexler 1961). LLJs can also develop or become enhanced in response to orography and soil moisture gradients (McCorcle 1988).

The southwesterly airstream component of the classic severe DMC pattern provides a mid-level dry-air intrusion from the Mexican Plateau, an environmental component commonly referred to as the elevated mixed layer (EML). The EML provides an inversion (cap) over the warm, moist, and potentially unstable PBL, inhibiting the 'release' of PBE (conversion of potential to kinetic energy). This allows $\mathrm{PBE}$ to build progressively over time until it is eventually released, due either to an increase in southerly low-level winds that forces air northward out from under the cap (a process known as 'underrunning'), small-scale cap erosion by strong and locally persistent updrafts (a process known as 'entrainment'), or large-scale cap removal due to passage of an upper-level shortwave or jet streak (Bluestein and Thomas 1984; Carlson and Ludlam 1968; Carlson et al. 1983; Harnack and Quinian 1989). Johns (1982) also recognizes a second important severe DMC synoptic circulation type; the northwesterly flow (NWF) event (Figures 5-7). The NWF synoptic type is characterized by a longwave trough axis centered east of the threat region with an upper-level northwesterly flow east of the corresponding upstream ridge. In cases of NWF events, an embedded shortwave propagates southeastward along the western side of the longwave trough providing meso- $\beta$-scale vertical motion sufficient to initiate convection when low-level PBE exists.

The greatest frequency of NWF outbreaks in North America tend to occur during middle and late summer (July through August) when the typical climatological longwave pattern (trough off the west coast and ridge centered over the Great Plains) has become established. Severe DMC storms are relatively common with these NWF patterns, although vertical speed shear is generally weaker than during the spring or fall with fewer tornadoes the result.

In summary, the classic synoptic-scale circulation types supportive of severe DMC storms have been well established. Unfortunately, the majority of work in this area, outside of individual case studies, has been specific to 


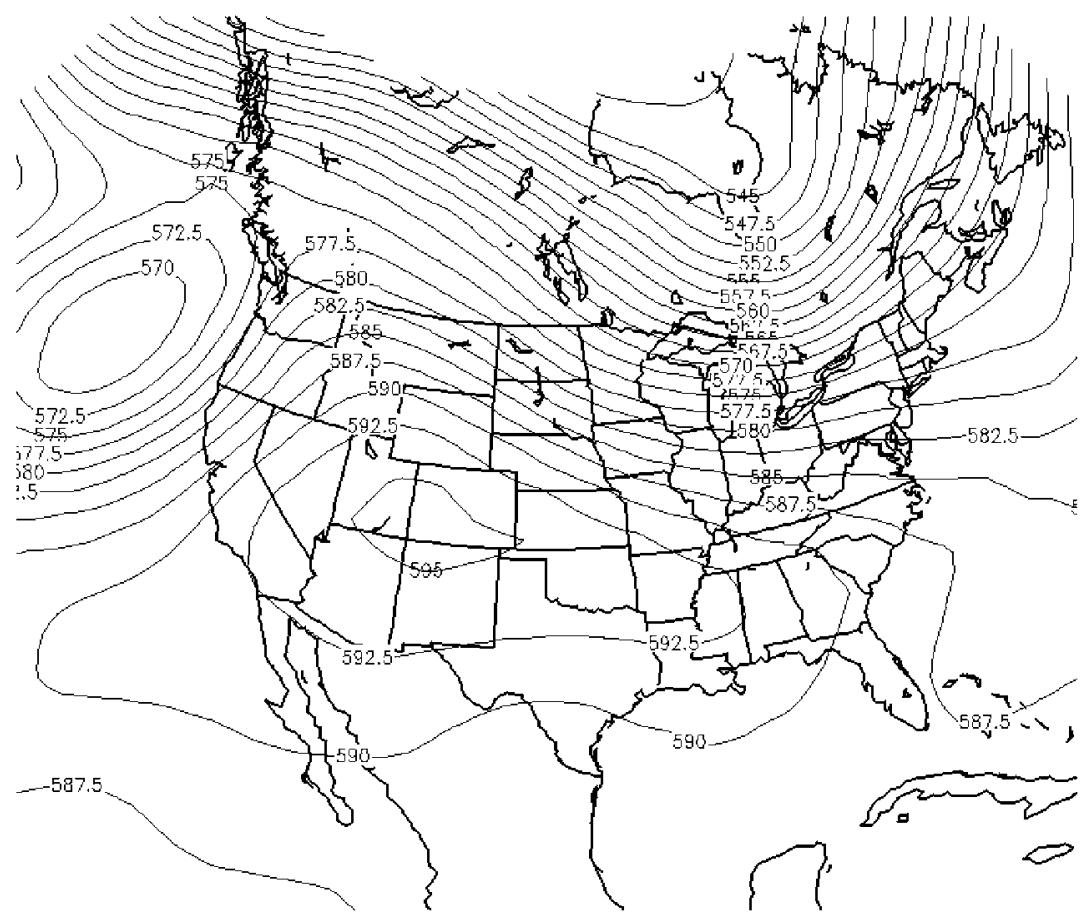

Fig. 5. Northwesterly flow event synoptic-scale $500 \mathrm{hPa}$ geopotential height pattern observed August 28, 1990. An unexpected violent (F5) tornado tracked through the southwest suburbs of Chicago during the middle afternoon killing 29 people.

the Great Plains region of North America. As a result, even within the United States, forecasters have had to rely upon synoptic models developed for regions very different from their own. This problem is even more significant outside of North America and Western Europe.

\subsection{MESO-SCALE DMC STORM TYPES}

Embedded within the larger-scale synoptic environments described above are important meso-scale circulations that result in a variety of storm types that exhibit specific characteristics. The four most widely recognizable DMC storm types are air mass thunderstorms (non-severe), multicell storms (both non-severe and severe), supercell storms (severe), and the Westplains hybrid storm. Despite the DMC storm types recognized by consensus over several decades, it should be noted that any storm classification system is of human construct and portrays only a rough approximation of the variability that likely exists within a continuum of reality.

Air mass thunderstorms develop in response to an adequate low-level moisture supply, conditionally unstable troposphere, and strong surface 


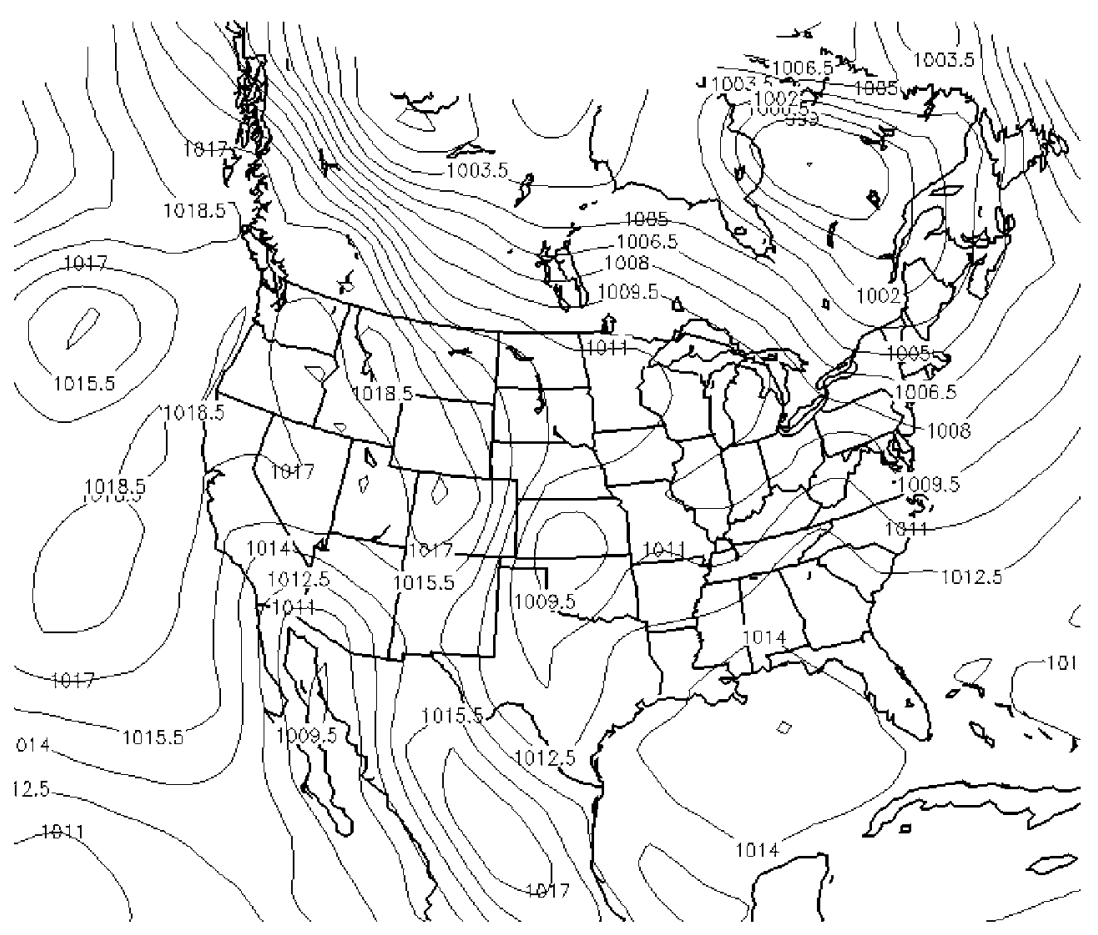

Fig. 6. Northwesterly flow event synoptic-scale sea-level pressure pattern observed August 28, 1990.

heating (Byers and Braham 1949). Their occurrence is considered to be spatially random when the synoptic circulation resembles the long-term mean pattern (Barnes and Newton 1986). The Thunderstorm Project of the late 1940s brought to light the general attributes of air mass storms, described as a short-lived convective system progressing through a series of lifecycle stages (i.e. cumulus, mature, decay) in a relatively short period of time (typically $1 \mathrm{hr}$ ) (Byers and Braham 1949). Convection is initiated as a low-level plume of warm moist air is forced upward by shallow meso- $\gamma$ scale baroclinic circulations generated by differences in surface heating from solar radiation. The DMC cell continues to grow in the vertical as latent heat is released through the condensation process. Rainfall begins, usually accompanied by thunder and lightning, when the growing water load becomes too great for the updraft to support. The storm begins to dissipate when the downdraft, generated by a combination of frictional drag imparted on the air by falling precipitation particles and evaporative cooling, pushes horizontally out and away from the storm. This cuts off the updraft that initially provided the storm its energy. Because the storm itself remains relatively stationary due to weak 'steering' winds aloft (an environment of weak vertical wind shear), convergence along the advancing gust front is 


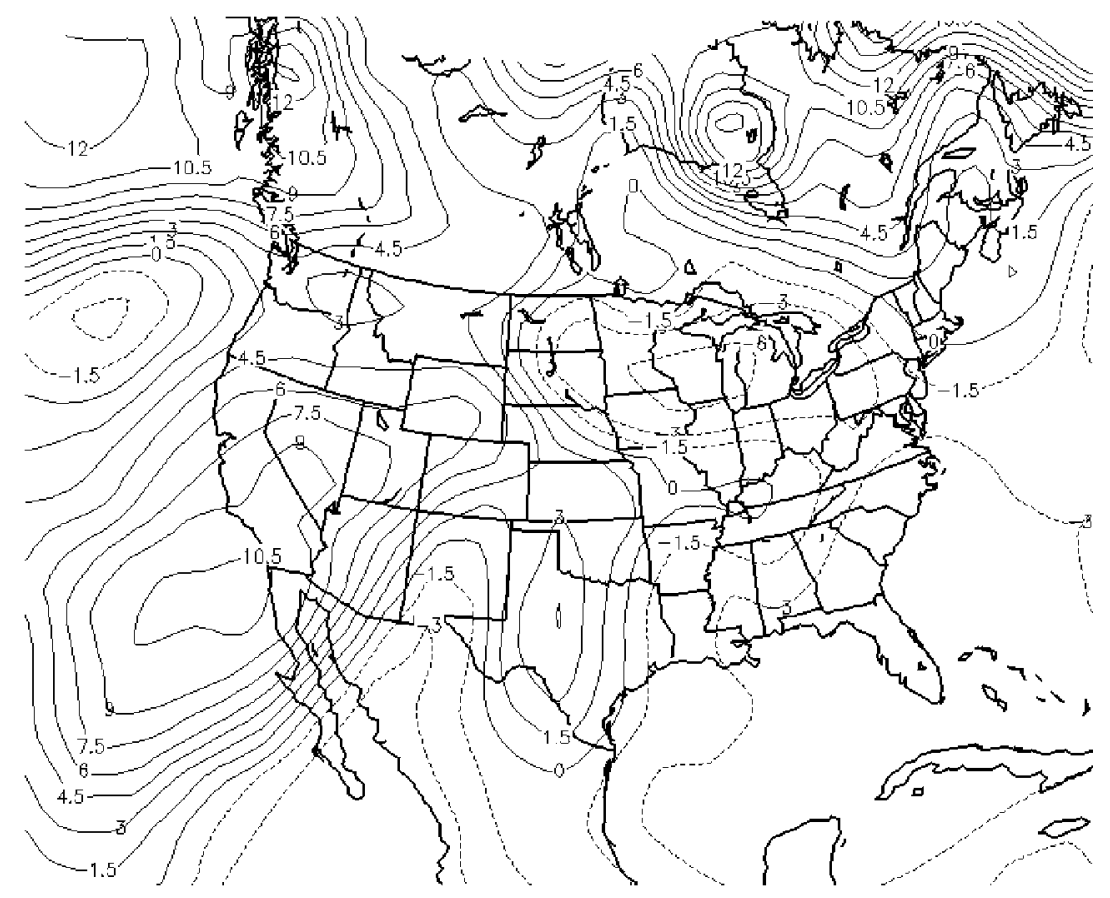

Fig. 7. Lifted index values for August 28, 1990.

usually very weak. As a result, most secondary cells are weaker than their predecessors (Klemp and Weisman 1983).

Single-cell air mass storms are capable of briefly reaching severe limits only if moisture supplies and instabilities are very large. This is possible where little competition (with other storms) exists for the environmental PBE. These briefly 'severe' storms are typically referred to as pulse storms, which by their very nature are extremely difficult to forecast (Devoir and Grumm 2005, http://nws.met.psu.edu/severe/2005/13Jun2005.pdf, last accessed August 1, 2007).

Severe multicell DMC storms can be described as a cluster of single cells, usually aligned in a geometrically quasi-linear pattern, that interact as a partially integrated system. Individual storms within the cluster compete with one another for available PBE that significantly influences the internal circulations of each (Marwitz 1972b). New cells tend to form on the right flank with respect to the mean $0-6 \mathrm{~km}$ environmental wind and progress through a lifecycle similar to that of air mass thunderstorms. As each cell continues to develop it propagates downwind toward the line's left flank where the inflow is blocked by newly developing cells to the right. As a result, the most intense cells are typically found on the right flank. Over 
time, it usually appears that the strongest cells are moving to the right of the mean environmental winds; however, this is actually the result of newer and stronger cells forming on the right flank of a southward growing line. This process is known as discrete propagation.

Multicell storms are characterized by winds that increase substantially with height above the earth's surface. This vertical speed 'shear' causes the vertical axis of the cells to tilt in the downstream direction. As a result, storm lifespans become greater because the developing precipitation is pushed downwind and away from the main updraft core. Longer duration (steady-state) storms have a much better chance of achieving the necessary circulation structure, providing energy requirements are met, for the production of severe weather. Strong winds aloft will also 'steer' the cluster along at speeds similar to those of the surface outflow boundary (gust front). Because the outflow boundary does not advance as far ahead of the storm, the updraft energy generated along the gust front is ingested directly into the parent storm. In many cases, this will satisfy the large energy demands of the growing storms such that they are able to become severe.

Another form of multicell storm is the squall line (Bluestein and Jain 1985; Hane 1986), more recently referred to as a quasi-linear convective system (QLCS) (Tessendorf and Trapp 2000; Weisman and Davis 1998; Wheatley and Trapp 2006). In most cases, QLCSs are associated with very strong winds aloft that advance the line rapidly enough so that the inflow of moisture and energy is enhanced along the leading edge (the east side of a northsouth line). If a north-south QLCS moves through a region of strong southerly flow, it is not unusual for the southernmost cell of the line to gain supercell characteristics and generate one or more strong tornadoes.

Supercell storms are single-cell systems that develop distinct rotation, very large hail, and on occasion, violent tornadoes (Browning 1964; Doswell et al. 1990; Lemon and Doswell 1979; Marwitz 1972a; Moller et al. 1990). They are large (20-50 km in diameter), long lasting (2-6 hr), steady-state storms that propagate continuously to the right (typically about $30^{\circ}$ ) of the mean 0-6 km environmental winds (Browning 1964; Leftwich 1990). The continuous right-moving propagation is forced by interaction of the storm's internal rotation with the large-scale environmental wind field. Classic rotating supercells, those that persist for several hours, require large $\mathrm{PBE}$ and significant vertical wind shear.

The deviation to the right of the mean environmental winds will enhance the storm relative inflow up to $5-10 \mathrm{~m} / \mathrm{sec}$ when low-level flow is from the south (Browning and Foote 1976). Enhanced inflow aids in moisture convergence that helps meet the tremendous PBE needs of such large and powerful storms. Once supercells begin to reach their mature stages they create a 'barrier' to the mid- and upper-level environmental flow. At this point movement slows, typically to about $75 \%$ of the mean 0-6 km wind speed, as the upper-level steering currents diverge around the storm's periphery (Eagleman and Lin 1977). 
The Westplains thunderstorm, identified by Foote and Frank (1983), is a hybrid of the classic supercell. This storm is most common in the arid High Plains of northeastern Colorado, and likely found in the more arid portions of Western Europe (especially Spain) and Australia. This severe DMC storm type exhibits many features of the classic supercell, although its lifespan is typically much shorter. What makes the Westplains storm distinct from the classic supercell is that after a period of time its structure degenerates into that of the more common multicell storm, only to rebuild to supercell proportions at a later time. This is primarily the result of strong directional vertical wind shear (winds that change direction rapidly with height - usually turning in a clockwise manner from the surface upward) within the PBL, but weak inflow and light winds aloft. It appears that the combination of low-level directional shear and large instability creates brief rotation; however, this rotation cannot be maintained for long periods of time due to the weak winds aloft. It is now believed that a substantial number of storms originally classified as either supercell or multicell, may have fit well into the Westplains category.

\subsection{MESO-SCALE DMC KINEMATIC ENVIRONMENTS}

In order for the most significant severe DMC storms (those which produce destructive hail and tornadoes) to develop, environmental winds must exhibit considerable vertical wind shear (Browning and Ludlam 1962). Vertical shear within severe DMC environments is typically expressed in two ways: (i) deep-layer speed shear (e.g. wind speed difference between the earth's surface and a height of $6 \mathrm{~km}$ above ground level; and (ii) low-level speed and directional shear.

Deep layer (speed) shear typically increases in response to an approaching mid-level shortwave (positive vorticity maximum) and/or upper-level jet streak, accompanied by significant thermal advection within an increasingly baroclinic environment. These environments are typical with approaching cyclones in their developmental stages. At low levels, veering wind (turning in a clockwise direction with height) represents warm advection, destabilization, and increasing upward vertical velocities, while a backing wind is associated with cold air advection, stabilization, and increasing subsidence. Weak deep layer vertical shear $(15 \mathrm{~m} / \mathrm{sec})$ in the lowest $6 \mathrm{~km}$ of the troposphere is typically supportive of only air mass DMC storms, while stronger shear is generally necessary for severe DMC storm types (Chisholm and Renick 1972; Djuric 1994; Thompson et al. 2004). Largely sheared environments support severe DMC storms because strong midtropospheric winds 'steer' them along at speeds proportional to that of the advancing gust front (leading edge of low-level downdraft-generated outflow air). This allows energy along the associated convergence boundary to be ingested into the cell, maintaining the large supply of PBE required for long-lived steady-state storms. Extremely sheared storms appear to break 
up the delicate balance in rotational forces (allowing for sufficient tilting and vertical stretching of low-level vortices) required for supercell formation in the absence of very large PBE (Djuric 1994). These environments seem to be more conducive to QLCS formation than supercell development (Bluestein and Jain 1985; Marwitz 1972c).

Once deep layer shear is sufficient to support severe (supercell) DMC storms and sustain rotation (Brooks and Wilhelmson 1994), the primary discriminating factors in tornadogenesis appear to be the PBL vertical shear (both direction and speed) and PBE environments that aid in the development of low-level updraft rotation (Davies 1989; Johns et al. 1990; Trapp 1999). It is well known that long-lived rotating storms develop in meso- $\beta$ scale environments exhibiting significant streamwise vorticity (horizontal vorticity parallel to the direction of the storm-relative inflow) and large inflow speeds $(>10 \mathrm{~m} / \mathrm{sec}$ ) (Davies-Jones 1984; Davies-Jones et al. 1990; Lazarus and Droegemeier 1990; Marwitz 1972a; Rotunno 1981). In today's operational forecasting environment, the parameter known as storm-relative environmental helicity (SREH) represents aggregate streamwise vorticity through the storm inflow layer (depths of $0-1,0-2$ and $0-3 \mathrm{~km}$ are commonly used) (Brooks et al. 1993; Davies-Jones 1984, 1990; Lilly 1986). Generally speaking, SREH is a function of shear-generated vorticity (due to veering winds that increase in speed with height), strength of the inflow winds, and storm motion. It is important to note when interpreting SREH values that they are very sensitive to depth of the inflow layer, with deeper layers almost always associated with larger values. Today, it is much more common to use shallow inflow layers of $0-1 \mathrm{~km}$ above ground level, than either $0-2$ or $0-3 \mathrm{~km}$ because it now appears strong vertical wind shear within the lowest $1 \mathrm{~km}$ of the PBL is most closely associated with tornadic supercells (Rasmussen 2003). Because perhaps only $20 \%$ of all supercells produce tornadoes (www.cimms.ou.edu/ doswell/Tornadostuff.html, last accessed August 1, 2007), the ability to discriminate between tornadic and non-tornadic supercells before tornado development would greatly improve the lead time between the issuance of tornado warnings and the event itself. Although success to this point has been limited, Edwards and Thompson (2000) and Rasmussen (2003) have suggested significant differences exist in mean $0-1 \mathrm{~km}$ SREH values between supercells that produce weak tornadoes $\left(105 \mathrm{~m}^{2} / \mathrm{sec}^{2}\right)$ and those that generate strong and violent tornadoes $\left(150 \mathrm{~m}^{2} / \mathrm{sec}^{2}\right)$. It is important to note however, that $0-1 \mathrm{~km} \mathrm{SREH}$ values of less than $100 \mathrm{~m}^{2} / \mathrm{sec}^{2}$ can be associated with supercells that produce strong and violent tornadoes if $\mathrm{PBE}$ is very large.

In summary, vertical wind shear represents one of the primary kinematic (horizontal wind pattern) parameters used in anticipating thunderstorm type (Browning 1964; Colquhoun and Shepherd 1989; Johns et al. 1990; Marwitz 1972a; Moncrieff 1978; Moncrieff and Green 1972; Moncrieff and Miller 1976; Riley and Colquhoun 1994; Weisman and Klemp 1982, 1984). The strongest shear environments are created by synoptic-scale circulations 


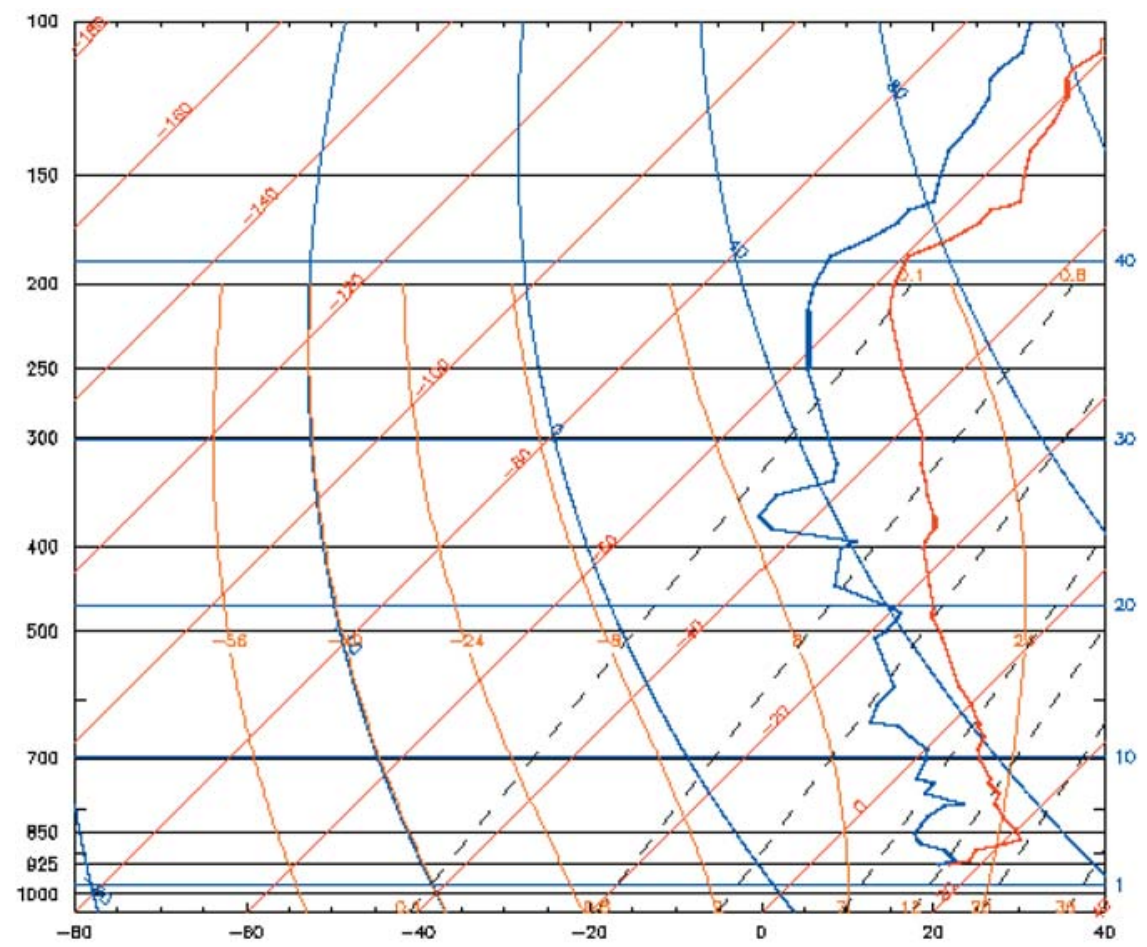

Fig. 8. Type A thermodynamic sounding (skew-T log-p) observed at Dodge City, Kansas, 12 UTC, May 31, 1999 (abscissa $=$ pressure $(\mathrm{hPa})$; ordinate $=$ temperature $\left({ }^{\circ} \mathrm{C}\right)$; solid red line $=$ environmental dry bulb temperature $\left({ }^{\circ} \mathrm{C}\right)$; broken red line $=$ dew point temperature) .

supportive of cyclogenesis, although local-scale modifications to these shear environments are becoming better recognized (e.g. Maddox et al. 1980).

\subsection{MESO-SCALE DMC THERMODYNAMIC ENVIRONMENTS}

While it is well known that vertical shear environments determine storm structure and type, it is tropospheric thermodynamics that dictate updraft/ downdraft intensity and the potential for DMC (Weisman and Klemp 1982). In general, thermodynamic data are provided by balloon soundings taken twice daily (00 and 12 UTC) at selected locations throughout the world. Recent advances in numerical weather prediction (at synoptic and mesoscales) have provided reasonable estimates of thermodynamic values between balloon launches, in some cases on an hourly basis (Davies and Johns 1993; Edwards and Thompson 2000). In most cases, soundings (whether measured or derived) are assessed graphically through the use of thermodynamic diagrams such as skew-T log-p, Stuve diagrams, or tephigrams.

There are three specific sounding types recognized as indicators of severe DMC storms (Browning 1986). The type A sounding (Figure 8), also known 


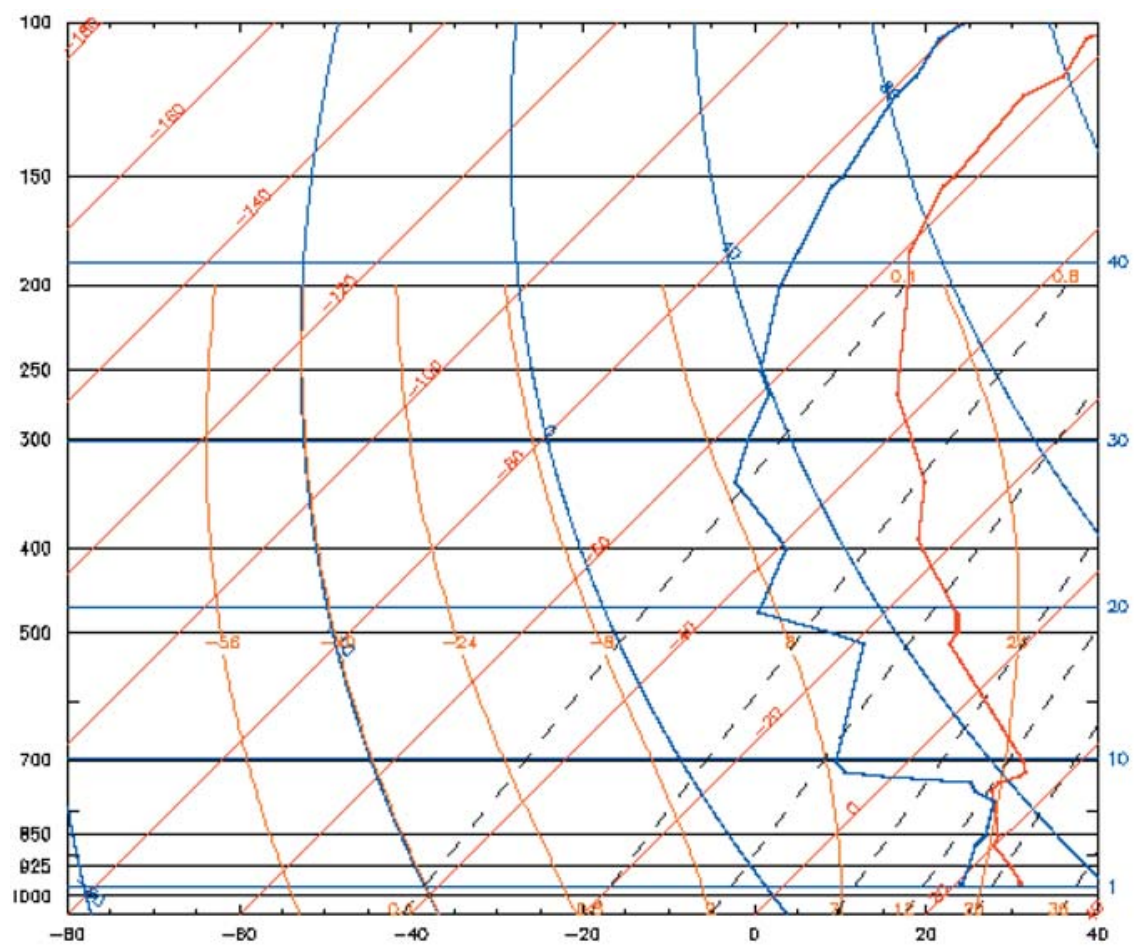

Fig. 9. Type B thermodynamic sounding observed at Omaha, Nebraska, 00 UTC, June 23, 2003.

as the inverted ' $\mathrm{V}$ ', represents arid low-level environments where the greatest water vapor concentrations are found elevated above the PBL (Beebe and Bates 1955). High cloud bases are common in these environments due to the low humidity, which promotes evaporation of much of the falling rain before it reaches the ground. This type of storm can produce brief but intense downdraft winds due to the strong evaporative cooling beneath the cloud base. Locations such as the Desert Southwest and Great Basin/ Prairies of North America, Mediterranean Europe, the highlands of Asia, and Western Australia commonly experience type A environments.

Type B soundings (Figure 9) are representative of the well-known 'loadedgun' profile typical of supercell environments in the North American Great Plains/Prairies (Fawbush and Miller 1953). They are characterized by an abundant supply of low-level moisture from the Gulf of Mexico and dry EML continental air advected from the west or southwest. This environment is quite favorable for the development of large PBE. In some cases, low-level moisture convergence is enhanced by the presence of a low-level jet, which also works to enhance vertical wind shear.

Type C soundings (Figure 10) are most common in humid subtropical climates. They are characterized by a deep layer of moisture through the 


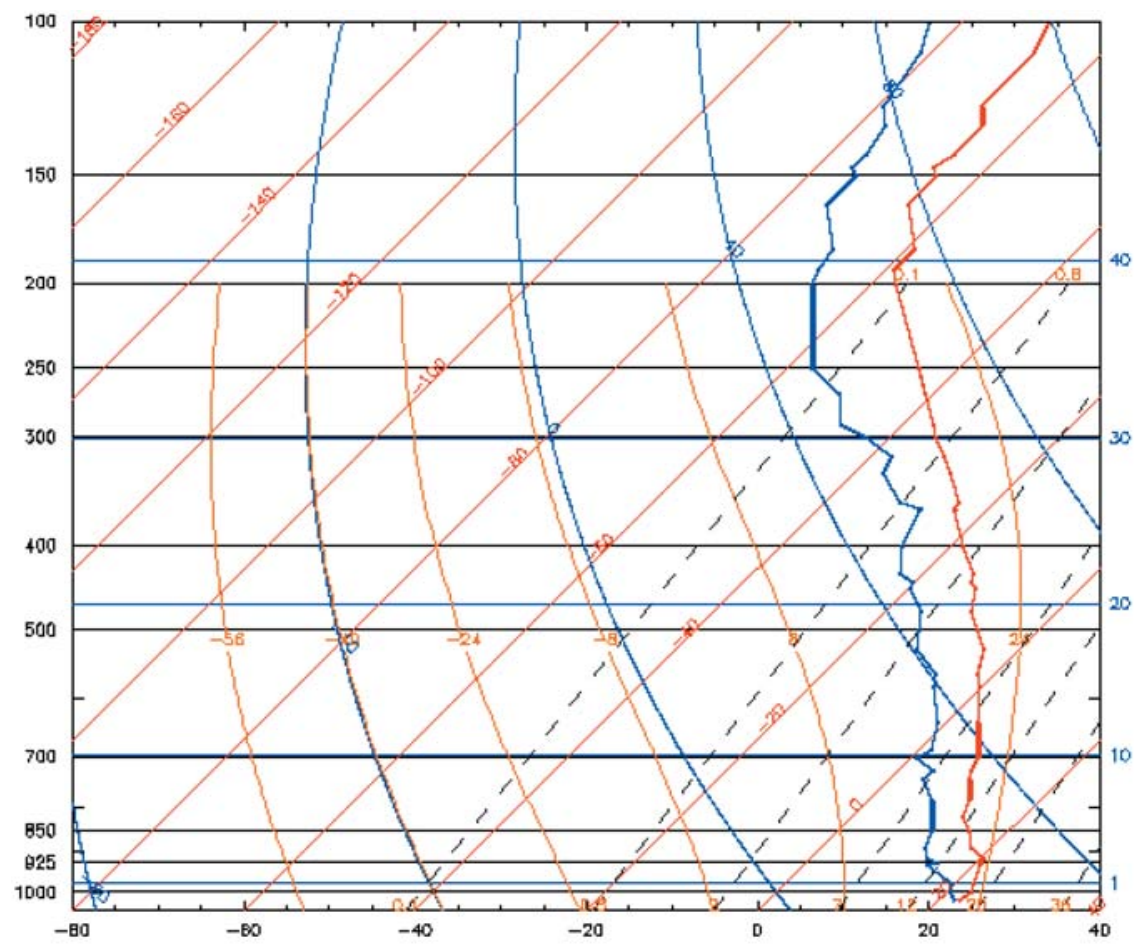

Fig. 10. Type C thermodynamic sounding observed at Tampa Bay, Florida, 12 UTC, July 4, 1999.

middle troposphere. Type $\mathrm{C}$ environments usually produce severe thunderstorms with very heavy rainfall, and tornadoes if sufficient low-level shear exists, but generally weak downdraft winds and small hail (Byers and Braham 1949). Severe DMC associated with type C environments are most commonly found in the southeastern United States, southern Japan, Southwest Asia, northeastern Australia and South Africa (Brooks 2006).

Related to the type $\mathrm{C}$ environment is the wet microburst sounding (Figure 11) identified by Read (1987). The wet microburst environment exhibits a deep layer of saturated air similar to the type C sounding, but is capped by a dry layer beginning near the $600 \mathrm{hPa}$ level. The dry air provides the evaporative 'power' necessary to produce large-negative PBE that frequently generates damaging surface winds.

There have been a wide range of hydrostatic stability 'indices' developed to represent PBE from the analysis of sounding data (Peppler 1988; Peppler and Lamb 1989). Some of the more traditional measures are the Lifted Index (LI), Showalter Index (SWI), K-index, and Total Totals Index. A popular method of estimating total PBE within a tropospheric column is through the use of convective available potential energy (CAPE) (Blanchard 1998). CAPE is proportional to the total kinetic energy an ascending air 


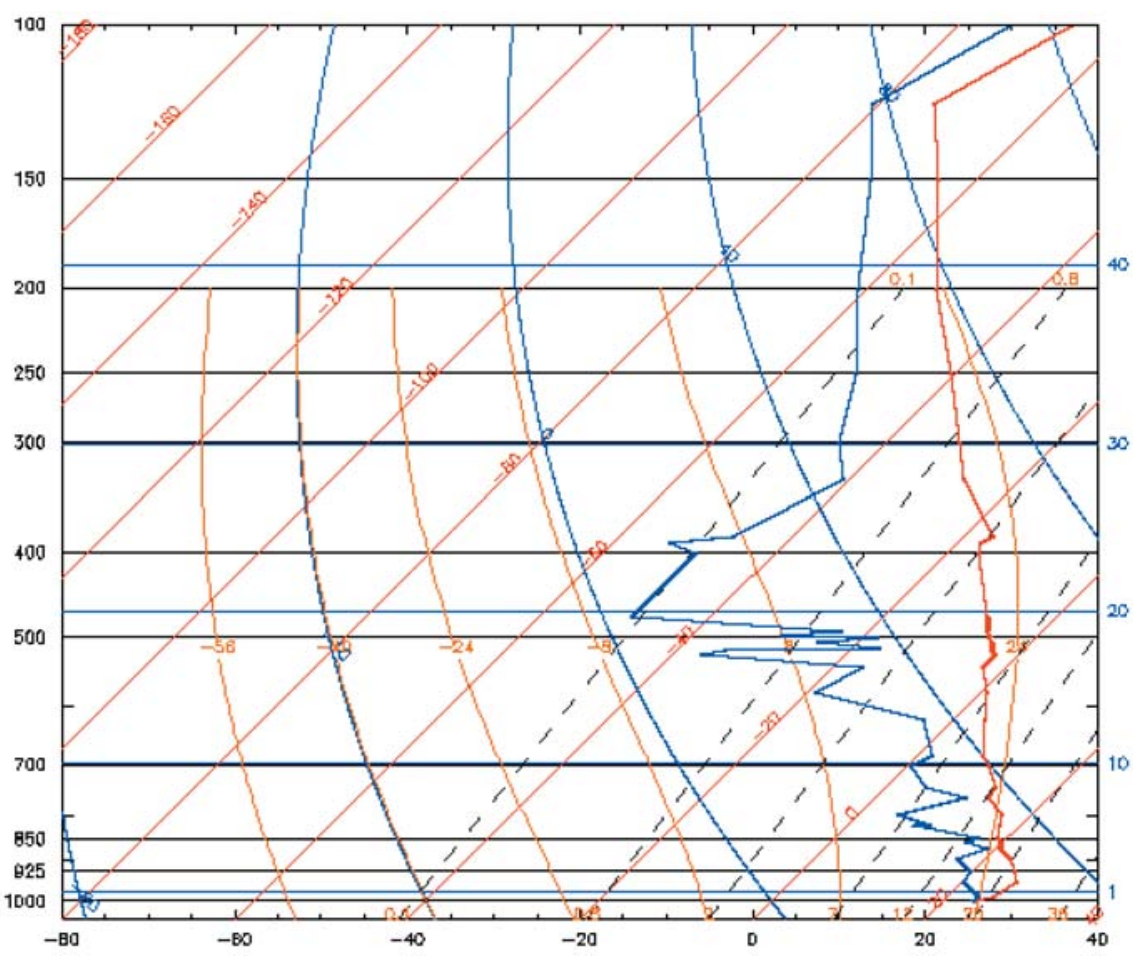

Fig. 11. Wet microburst sounding observed at Nashville, Tennessee, 12 UTC August 1, 2006.

parcel may attain due to differences between parcel virtual temperature and that of the surrounding environment (Djuric 1994).

Another important 'thermodynamic' parameter used to assess the potential for severe DMC initiation is cap strength. Cap strength represents the ability of the low-level inversion, created by the EML, to inhibit deep convection thus allowing PBE levels to continue building over time. If convection is delayed until late afternoon when PBE levels reach a peak, then cells that penetrate the cap may contain enough kinetic energy to meet the requirement for developing supercells. A strong cap is a critical component to the type B loaded-gun 'tornado' sounding, and is clearly an important parameter to consider when attempting to determine storm type (Graziano and Carlson 1989).

Although forecasting hail size can be very difficult, it has been shown that height of the wet-bulb zero surface (WBZ) can be a somewhat successful predictive parameter. The WBZ provides an estimation of the freezing level in saturated air (Johns and Doswell 1992), with lower WBZ heights more supportive of large hail. For example, in a study of 529 hailstorms, Miller (1972) found that 71\% were associated with WBZ heights of between $2100-3400 \mathrm{~m}$, as were $84 \%$ of all storms that produced large hail 
( $\geq 2 \mathrm{~cm}$ ), while very large-hail events $(\geq 7 \mathrm{~cm})$ were associated with WBZ heights of $2100-2750 \mathrm{~m}$. Heights greater than $3200 \mathrm{~m}$ seemed to provide sufficient time for the complete melting of all but the largest hailstones.

Another thermodynamic parameter of interest is precipitable water (PW), the primary measure of columnar tropospheric water content. PW is calculated as the depth of liquid water that would result if all moisture were condensed from a tropospheric column. In general, PW values greater than $25 \mathrm{~mm}$ are typically associated with the formation of heavy rainfall producing thunderstorms (Djuric 1994).

Because it is neither the kinematic (general circulation pattern) nor thermodynamic environments alone that determine the potential for severe DMC storm types, perhaps the most efficient way to analyze the total prestorm environment is through an integration of both $\mathrm{PBE}$ and vertical shear parameters. This is commonly performed through the analysis of three primary combined indices: (1) the bulk Richardson number (BRN); (2) the Energy-Helicity Index (EHI), and (3) the Severe Weather Threat (SWEAT) Index.

The BRN is a ratio of CAPE to vertical shear (Weisman and Klemp 1982, 1984). It provides an estimation of the contribution of energy from thermodynamic and kinematic sources. For example, large (small) BRN values are indicative of high (small) potential energy, and weak (strong) kinetic energy environments. It is also known that an inverse relationship exists between BRN and storm intensity; supercell storms tend to be associated with BRNs less than 45, and multicell storms with BRNs greater than 45 (Ray 1990; Weisman and Klemp 1984, 1986).

Another valuable measure of the combined thermodynamic and kinematic environments is the EHI (Hart and Korotky 1991). The EHI is a simple ratio of CAPE to SREH and provides a very good estimate of the potential for persistent updraft rotation necessary for the development of supercell storms (Lazarus and Droegemeier 1990).

Perhaps waning in popularity, but still used by some forecasters is the SWEAT index (Miller 1972). The SWEAT is a non-dimensional parameter based on several thermodynamic and kinematic parameters, including available moisture, instability, and vertical shear. SWEAT values greater than 300 suggest the potential for severe DMC development, while values greater than 400 imply supercells are likely.

There is much disagreement among operational meteorologists as to which of the aforementioned indices are superior. Some meteorologists become particularly attached to a specific index, while others use several in combination. It is also quite likely that these parameters are region sensitive as well.

\subsection{LAND-SURFACE-ATMOSPHERE INTERACTIONS}

Deep moist convective initiation attributed to surface forcing is the result of meso-scale PBL circulations that can be grouped into two categories: 
those related to thunderstorm outflow boundaries and those due to surface heterogeneities. Recognition of these meso- to local-scale processes may be important in explaining the spatial clustering of severe events observed on many severe thunderstorm and tornado spatial distribution representations.

Boundary layer convergence between old thunderstorm outflow boundaries, or between old outflows and frontal boundaries, has been shown to trigger deep convection or enhance updrafts in existing DMC circulations. It may be these convective enhancements that force DMC storms beyond severe thresholds (Maddox et al. 1980; Mahoney 1988; Purdom 1976). Schreiber (1986) and Wilson and Schreiber (1986), in studies of eastern Colorado thunderstorms, however, found that only about half of the observed convergence boundaries originated from old thunderstorm outflows; the remaining 50\% were attributed to 'unknown' sources. Therefore, it seems plausible that meso-scale circulations that develop in response to surface heterogeneity may account for some of the unknown sources linked to the initiation and enhancement of severe convection.

Meso-scale circulations generated in response to surface heterogeneity, referred to as non-classical meso-scale circulations (NCMC) by Segal and Arritt (1992), can result in significant mass and moisture convergence along land-cover boundaries and produce upward vertical circulations approaching the magnitudes of sea breezes (Mahfouf et al. 1987; Ookouchi et al. 1984). Most of these NCMCs are related to spatial differences in (i) soil moisture due to natural rainfall and/or irrigation (Barnston and Schickendanz 1984; Pielke and Zeng 1989; Rabin et al. 1990); (ii) vegetation (Anthes 1984; Brown and Arnold 1998; Garrett 1982; Pinty et al. 1989; Segal et al. 1988); (iii) cloud-shading effects (Bailey et al. 1981; Segal et al. 1986; Skupniewicz et al. 1991); (iv) differential terrain heating (Benjamin 1986; Benjamin and Carlson 1986; Pielke and Segal 1986); (v) surface albedo (Mahrer and Pielke 1978; Physick and Tapper 1990; Segal et al. 1986); (vi) the presence of water bodies (Chandik and Lyons 1971; Keen and Lyons 1978; Lyons 1966; Pearson 1958); and (vii) the existence of urban areas (Braham and Wilson 1978; Changnon 1978).

Pielke and Zeng (1989) have argued that it is not the enhanced upward vertical velocities associated with NCMC convergence alone that can produce or enhance severe convection. The augmented moisture supply and increase in PBE provided by the wetter (and usually cooler) surfaces play an important role as well. In a study of radiosonde data over an irrigated area and adjacent natural grassland, it was found that the Lifted Index changed from a positive 3.0 (hydrostatically stable) over the dry grassland to negative 6.8 (highly unstable) over the irrigated area. The authors further suggest enhancement of pre-existing thunderstorms along these boundaries could be significant enough for the production of tornadoes.

The aforementioned surface forcing mechanisms seem to also play a role in the initiation of convection (Carleton et al. 2001, forthcoming 2008a,b; Chang and Wetzel 1991; Pielke and Segal 1986), the erosion of the 
inversion lid (Benjamin and Carlson 1986; Lanicci and Warner 1991), and the intensification (dissipation) of migrating convective storms due to the enhancement (decrease) of convective instability and/or mass convergence (Maddox and Doswell 1982). For example, Johns and Doswell (1992) suggest baroclinic boundaries that develop in response to the diabatic processes discussed above may significantly disrupt low-level moisture flows that can impact the convective pattern over relatively large (meso- $\beta$-scale) regions. Maddox et al. (1980) also suggest that thunderstorms intensify as they cross thermal (meso-scale) boundaries, and because local shear environments are enhanced along these boundaries, 'mini-outbreaks' of intense tornadoes can result. These boundaries become very important when the larger synoptic-scale environments do not favor large outbreaks of severe DMC storms; although Chang and Wetzel (1991) have indicated their identification may aid in determining the location of severe DMC trigger points even in highly sheared large-scale environments. Wakimoto and Wilson (1989) further suggest that some of the more devastating tornadoes may occur when supercell storms ingest the shearing instabilities generated along these surface convergence boundaries.

\subsection{DOWNBURST EVENTS}

Perhaps the most underestimated severe DMC threat from a general public perspective is the damaging 'straight-line' (non-tornadic) wind, or more properly, downburst event. Downburst events are much more common than tornadoes, and produce similar damage as weaker tornadoes (the large majority of tornadoes are actually not considered to be either strong or violent). However, public perception seems to be that downburst winds are not as strong as winds produced by tornadoes, and that somehow all tornadoes are quite violent (Hitchens and Arnold 2005). As a result, there is less attention paid to warnings issued for these events, and more people caught by surprise when they develop.

Downburst winds are thunderstorm downdrafts that exceed $25 \mathrm{~m} / \mathrm{s}$, the result of very large downward accelerations within convective circulations. They are a function of both evaporative cooling and the drag created by falling hydrometers (Doswell 1982). Storms that ingest large volumes of dry mid-level air (3-7 km above ground level) tend to generate the strongest downdrafts due to large-negative buoyancy enhanced through evaporation (Brandes 1977; Foster 1958). Evaporative cooling can also be enhanced by steep lapse rates that help to maintain negative buoyancy (Kamburova and Ludlam 1966; Srivasrava 1985). While storms of this nature usually produce the most intense straight-line wind damage, they are more easily forecast than either large hail or tornadoes because they depend more on dry intrusions more easily identified at the synoptic scale.

Thunderstorm-generated severe straight-line wind events can be classified into two categories: downbursts and derechos. A downburst is defined as 
a strong divergent downdraft that creates a 'burst' of damaging wind at or near the earth's surface (Fujita 1978, 1979). Downbursts are further classified as either macrobursts or microbursts, according to their length scales. Macrobursts produce the largest downbursts with horizontal dimensions exceeding $4 \mathrm{~km}$, while microbursts are smaller with a maximum horizontal extent of $4 \mathrm{~km}$. Downbursts have accounted for several airline crashes worldwide (Fujita and Byers 1977).

Derechos are widespread convectively induced windstorms composed of downburst families (Fujita and Wakimoto 1981; Johns and Hirt 1987). To meet the formal definition, wind gusts must exceed $26 \mathrm{~m} / \mathrm{sec}$ (50 knots) along a minimum axis of $400 \mathrm{~km}$, and wind damage reports must show a chronological progression with at least three reports of significant damage. Derechos are usually associated with squall lines and bow echoes (Burgess and Smull 1990; Fujita 1978, 1981; Schmidt and Cotton 1989).

Thermodynamic parameters are the best indicator of the potential for downbursts in weakly sheared kinematic environments (Johns and Doswell 1992). Downbursts are typically associated with type A (Figure 8) and wet microburst (Figure 11) soundings in weak shear environments, although not all wet microburst patterns produce downbursts. Atkins and Wakimoto (1991) have found that downbursts are much more frequent on days in which the vertical difference in equivalent potential temperature between the surface and mid-levels is $\geq 20^{\circ} \mathrm{C}$.

Severe storms associated with weak shear environments are generally of the multicell variety (Marwitz 1972b), but can be manifest as warm season bow-echo derechos under extremely unstable conditions (type B sounding). The tremendous instability contributes to the formation of an elevated rearinflow jet that is associated with the development and maintenance of a progressive warm-season derecho (Augustine and Zipser 1987; Smull and Houze 1987).

Moderate to extremely sheared environments produce not only the greatest number of severe straight-line wind events, but also the most intense damage (Johns and Doswell 1992). Most of these environments are characterized by the loaded-gun type B thermodynamic profile. A strongly sheared troposphere tends to generate supercells that are capable of producing considerable downburst wind damage, although damage is also possible from intense inflow winds. Extremely sheared environments (Marwitz 1972c) are related to serial derechos (line-echo wave patterns) that produce the most widespread damage of any storm type, excluding long-track tornadoes (Johns 1993).

\subsection{NON-SUPERCELL TORNADOES}

While the great majority of strong and violent tornadoes are associated with supercells (Kelly et al. 1978), there are many non-supercell tornadoes that produce only light-to-moderate damage over small areas. The relative frequency of these tornadoes is unknown because they are rarely detectable 
on radar, even with the new NEXRAD-type systems, and many go unobserved in rural areas. As a result, non-supercell tornadoes are extremely difficult to forecast.

Although non-supercell tornadoes are generally much weaker than their counterparts, there have been cases where they become very strong and large, causing a great deal of damage. Injuries and fatalities with these tornadoes have also been reported (Fujita 1981; Wakimoto and Wilson 1989). While the processes responsible for their development are not yet fully understood, non-supercell tornadoes can be grouped into three general classes: (i) flanking line tornadoes; (ii) cold air funnels; and (iii) shear-zone tornadoes.

Flanking line tornadoes, more recently recognized as 'landspouts', form under lines of developing cumulus congestus due to the vertical tilting of horizontal vorticity and subsequent stretching of vortex 'tubes' (Wakimoto and Wilson 1989). The tilting of horizontal vorticity is most commonly produced by intersecting outflow boundaries (Barnum et al. 1970; Bluestein 1985; Burgess and Davies-Jones 1979; Davies-Jones and Kessler 1974; Moller 1980).

Cold air funnels (Cooley 1978) develop from low-topped cumulonimbus clouds due to the destabilizing effect of a cold upper-level trough. The lifespan of these funnels is brief with an average duration of a few minutes. They rarely approach the ground and produce very little, if any, damage.

Shear-zone tornadoes can be subdivided into two groups: gust-front tornadoes and microburst-generated tornadoes. Gust front tornadoes, or 'gustnadoes' are the weakest and shortest-lived of all DMC vorticies. In general, they develop as weak horizontal vorticity generated along surface outflow boundaries becomes vertically tilted (Brandes 1977; Burgess and Donaldson 1979; Fujita 1979; Wakimoto and Wilson 1989). Gustnadoes, while not really tornadoes at all, occur along the leading edge of gust fronts as low-level horizontal shear that develops across the boundary produces hydrodynamic instability that generates small vortices at horizontal intervals of 10-15 km (Carbone 1982).

Microburst-generated tornadoes develop in response to shear instabilities created along the leading edge of strong low-level outflow winds (Barcilon and Drazin 1972; Forbes and Wakimoto 1983; Fujita 1979). In this case, the horizontal vorticity develops rapidly as intense downdrafts transport strong horizontal momentum into the boundary layer. Tornadoes form when the vortex tube becomes tilted and stretched into the inflow. Fujita (1979) has suggested that tornado intensity can become strong when these vorticies are ingested into developing mesocyclones along a bow echo, a situation not uncommon with QLCSs (Tessendorf and Trapp 2000).

\section{The Future of Severe DMC Mitigation}

Although mitigation of natural hazards has long been an interest of human societies, the awareness of recent disaster events due to improved global 
communications, better understanding of the processes involved, and the evolution of technology necessary to monitor our physical systems have led to a much greater focus on mitigation planning in recent years. National and international organizations have developed to address mitigation planning issues (e.g. International Society for the Prevention and Mitigation of Natural Hazards, Natural Hazards Center at the University of Colorado, Centre d' Etude des Risques Geologiques), and some governments now even require mitigation plans be filed ahead of any disaster for recovery money to be made available to the affected communities.

While larger-scale natural disasters such as earthquakes, tsunamis, and tropical cyclones clearly represent our most conspicuous hazards, it is the smaller-scale severe DMC storms that are most likely to impact local-scale communities with little advanced warning. Although some attention has been paid to improving warning systems for these storms through research investigating severe DMC processes and atmospheric monitoring on local scales, successful mitigation is a three-step process involving preparedness, response, and recovery. Preparedness requires us to not only forecast and monitor the evolution of such events, but it also necessitates an awareness of the risks involved by the general public, and development of individual plans of action to be carried out once that threat is imminent. Unfortunately, most citizens are unaware of the severe DMC threats they face, and as a result, are poorly prepared to respond.

As time progresses, we will continue to see an improved understanding of atmospheric processes and the technology necessary to monitor them. For example, plans are already in place for significant improvements to Doppler weather surveillance radar in the form of phased-array (Fenn et al. 2000) and dual-polarization systems (Tang and Bringi 2003). The resolution and physics of numerical weather prediction models is also improving such that their ability to forecast meso- $\beta$ MCS behavior is already on the horizon (Kuo 2003). Yet, with our improved understanding of severe DMC processes and the technology to monitor them, little true improvement in mitigation is likely until the general population better understands the true threat for DMC storms within their communities.

It is well known that when people understand a threat exists, they are better prepared to take action when that threat becomes reality. These actions, if appropriate and carried out in expeditious fashion, can save lives, minimize property damage, and reduce human suffering (National Science and Technology Council 2000). The ability to carry out these actions in expeditious fashion is predicated on receiving warning of the impending disaster (with enough lead time), and in understanding appropriate actions for the threat presented. When the public does not perceive nor recognize a threat, it is not likely to understand what action is appropriate when a warning is issued. In the case of a 'rare event' such as any severe DMC storm occurrence that affects a single person, home, or small group of people and structures, the real threat may not easily be recognized. Because it appears 
that public awareness of the severe DMC threat is the primary factor in determining whether appropriate action is taken immediately following a severe thunderstorm or tornado warning (Doswell et al. 1999), perhaps the most significant future growth potential in the area of DMC mitigation is in education of the general public. Advances as significant as those of Finley in the late 19th century, Fawbush and Miller in the 1950s, the advent of operational Doppler radar in the late 1980s, and continued improvement in meso-scale numerical weather prediction likely in the 21 st century, will have little impact on our societies in general unless the public better understands how to convert that information into appropriate action.

\section{Short Biography}

David L. Arnold is an Assistant Professor of Geography, Frostburg State University, Frostburg, Maryland, USA. He holds a BS from the University of Nevada-Reno (1984), MS from the University of Idaho (1989), and $\mathrm{PhD}$ from Indiana University (1994). Dr. Arnold teaches courses in Physical Geography, including climate dynamics, oceanography, natural hazards, and spatial analysis. His research interests include inter-annual atmospheric variability, deep moist convection, severe thunderstorms and tornadoes, and the Circumpolar Arctic. He has published on land-surface-atmosphere interactions, deep moist convection, and radar remote sensing in The International Journal of Climatology, Journal of Climate, Geophysical Research Letters, and The Encyclopedia of Climatology. He is a member of the American Meteorological Society, and has served as Broadcast Seal of Approval Examining Committee Chairperson for the National Weather Association. Dr. Arnold has been chasing severe thunderstorms and tornadoes since 1982, and has operated a severe thunderstorm and tornado observation field course annually since 1995.

\section{Note}

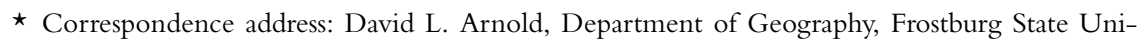
versity, Frostburg, MD 21532, USA. E-mail: dlarnold@frostburg.edu.

\section{References}

Adler, R. F., and Fen, D. D. (1978). Thunderstorm intensity as determined from satellite data. Journal of Applied Meteorology 18, pp. 502-517.

. (1980). Spiral feature observed at top of rotating thunderstorm. Monthly Weather Review 109, pp. 1124-1129.

- (1981). Satellite-observed cloud-top height changes in tornadic thunderstorms. Journal of Applied Meteorology 20, pp. 1369-1375.

Adler, R. F., Markus, M. J., and Fen, D. D. (1985). Detection of severe Midwest thunderstorms using geosynchronous satellite data. Monthly Weather Review 113, pp. 769-781.

Anthes, R. A. (1984). Enhancement of convective precipitation by mesoscale variations in vegetative covering in semi-arid regions. Journal of Climate and Applied Meteorology 23, pp. $541-554$. 
Arnold, D. L. (2005). Radar, climatic implications. In: Oliver, J. E. (ed.) Encyclopedia of world climatology. Dordrecht, Germany: Springer, pp. 601-603.

Atkins, N. T., and Wakimoto, R. M. (1991). Wet microburst activity over the southeastern United States: implications for forecasting. Weather and Forecasting 6, pp. 470-482.

Augustine, J. A., and Zipser, E. J. (1987). The use of wind profiles in a mesoscale experiment. Bulletin of the American Meteorological Society 68, pp. 4-17.

Ayra, S. P. (1988). Introduction to Micrometeorology. San Diego, CA: Academic Press.

Bailey, K. J., et al. (1981). A mesoscale forecast for 14 August 1975 - The Hampstead Storm. Meteorological Magazine 110, pp. 147-161.

Barcilon, A., and Drazin, P. (1972). Dust devil formation. Geophysical Fluid Dynamics 4, pp. 147-159.

Barnes, S. L., and Newton, C. W. (1986). Thunderstorms in the synoptic setting. In: Kessler, E. (ed.) Thunderstorm morphology and dynamics. Norman, OK: University of Oklahoma Press, pp. $75-111$.

Barnston, A. G., and Schickedanz, P. T. (1984). The effect of irrigation on warm season precipitation in the southern Great Plains. Journal of Climate and Applied Meteorology 23, pp. $865-888$.

Barnum, D. C., et al. (1970). F. C. Bates' conceptual thoughts on severe thunderstorms. Bulletin of the American Meteorological Society 51, pp. 481-488.

Barratt, P., and Browne, I. C. (1953). A new method of measuring vertical air currents. Quarterly Journal of the Royal Meteorological Society 79, p. 550.

Beebe, R. G., and Bates, F. C. (1955). A mechanism for assisting in the release of convective instability. Monthly Weather Review 83, pp. 1-10.

Benard, H. (1901). Les tourbillons cellularies dans une nappe liquide transport de la chaleur par convection en regime permanent. Annales de Chimie et de Physique 23, pp. 62-144.

Benjamin, S. G. (1986). Some effects of surface heating and topography on the regional severe storm environment Part II: two-dimensional idealized experiments. Monthly Weather Review 114, pp. 330-343.

Benjamin, S. G., and Carlson, T. N. (1986). Some effects of surface heating and topography on the regional severe storm environment Part I: three-dimensional simulations. Monthly Weather Review 114, pp. 307-329.

Bjerknes, J., and Holmboe, J. (1944). On the theory of cyclones. Journal of Meteorology 1, pp. $1-22$.

Blackadar, A. K. (1957). Boundary layer wind maxima and their significance for the growth of nocturnal inversions. Bulletin of the American Meteorological Society 38, pp. 283-290.

Blanchard, D. O. (1998). Assessing the vertical distribution of convective available potential energy. Weather and Forecasting, 13, pp. 870-877.

Bluestein, H. B. (1985). The formation of a 'landspout' in a 'broken line' squall line in Oklahoma Preprints. 14th Conference on Severe Local Storms. Indianapolis, IN: Indiana American Meteorological Society, pp. 267-270.

Bluestein, H. B., and Jain, M. H. (1985). Formation of mesoscale lines of precipitation: severe squall lines in Oklahoma during the spring. Journal of the Atmospheric Sciences 42, pp. 1711-1732.

Bluestein, H. B., and Thomas, K. W. (1984). Diagnosis of a jet streak in the vicinity of a severe weather outbreak in the Texas Panhandle. Monthly Weather Review 112, pp. 2499-2529.

Bonner, W. D. (1966). Case study of thunderstorm activity in relation to the low-level jet. Monthly Weather Review 94, pp. 167-178.

- (1968). Climatology of the low-level jet. Monthly Weather Review 96, pp. 833-850.

Bradford, M. (1999). Historical roots of modern tornado forecasts and warnings. Weather and Forecasting 14, pp. 484-491.

Braham, R. R., and Wilson, D. (1978). Effects of St. Louis on convective cloud heights. Journal of Applied Meteorology 17, pp. 587-592.

Brandes, E. A. (1977). Flow in severe thunderstorms observed by dual-Doppler radar. Monthly Weather Review 105, pp. 113-120.

Brooks, H. E. (2006). A global view of severe thunderstorms: estimating the current distribution and possible future changes Preprints. 18th Conference on Climate Variability and change. American Meteorological Society, Atlanta, Georgia. 
Brooks, H. E., Doswell, C. A. III, and Davies-Jones, R. (1993). Environmental helicity and the maintenance and evolution of low-level mesocyclones. In: Church, C., et al. (eds) The tornado: its structure, dynamics, prediction, and hazards, Geophysical Monograph. Washington, DC: No. 79 American Geophysical Union, pp. 97-104.

Brooks, R. A., and Wilhelmson, R. B. (1994). The role of mid-tropospheric wind in the evolution and maintenance of low-level mesocyclones. Monthly Weather Review 122, pp. 126-136.

Brown, M. E., and Arnold, D. L. (1998). Land surface atmosphere interactions associated with deep convection in Illinois. International Journal of Climatology 18, pp. 1639-1655.

Browning, K. A. (1964). Airflow and precipitation trajectories within severe local storms which travel to the right of the winds. Journal of Atmospheric Sciences 21, pp. 634-639.

- (1986). Morphology and classification of middle-latitude thunderstorms. In: Kessler, E. (ed.) Thunderstorm morphology and dynamics. Norman, OK: University of Oklahoma Press, pp. $133-152$.

Browning, K. A., and Foote, G. B. (1976). Airflow and hail growth in supercell storms and some implications for hail suppression. Quarterly Journal of the Royal Meteorological Society 102, pp. $499-533$.

Browning, K. A., and Ludlum, F. H. (1962). Airflow in convective storms. Quarterly Journal of the Royal Meteorological Society 88, pp. 117-135.

Brunt, D. (1937). Natural and artificial clouds. Quarterly Journal of the Royal Meteorological Society 63, pp. 277-288.

Burgess, D. W., and Davies-Jones, R. P. (1979). Unusual tornadic storms in eastern Oklahoma on 5 December 1975. Monthly Weather Review 107, pp. 451-457.

Burgess, D. W., and Donaldson, R. J. (1979). Contrasting tornadic storm types Preprints. 11th Conference on Severe Local Storms. American Meteorological Society, Kansas City, Missouri, pp. 189-192.

Burgess, D. W., and Smull, B. F. (1990). Doppler radar observations of a bow echo associated with a long-track severe windstorm Preprints. 16th Conference on Severe Local Storms. Kananaskis Park Alberta American Meteorological Society, pp. 203-208.

Byers, H. R., and Braham, R. R. Jr (1949). The thunderstorm. Washington, DC: United States Department of Commerce.

Carbone, R. E. (1982). A severe frontal rainband Part I: stormwide hydrodynamic structure. Journal of the Atmospheric Sciences 39, pp. 258-279.

Carleton, A. M., Arnold, D. L., and Travis, D. J. (forthcoming 2008a). Synoptic circulation and land surface influences on convection in the Midwest US 'Corn Belt', Summers 1999 and 2000 Part I: synoptic composite environments. Journal of Climate.

Carleton, A. M., Travis, D. J., and Arnold, D. L. (forthcoming 2008b). Synoptic circulation and land surface influences on convection in the Midwest US 'Corn Belt' Summers 1999 and 2000 Part II: effects of vegetation boundaries. Journal of Climate.

Carleton, A. M., et al. (2001). Summer season land cover - convective cloud associations for the Midwest US 'Corn Belt'. Geophyscial Research Letters 28, pp. 1679-1682.

Carlson, T. N., and Ludlum, F. H. (1968). Conditions for the occurrence of severe local storms. Tellus 20, pp. 203-226.

Carlson, T. N., Benjamin, S. G., and Forbes, G. S. (1983). Elevated mixed layers in the regional severe storm environment: Conceptual model and case studies. Monthly Weather Review 111, pp. $1453-1473$.

Chandik, J. F., and Lyons, W. A. (1971). Thunderstorms and the lake breeze front Preprints. 7th Conference on Severe Local Storms. American Meteorological Society, Kansas City, Missouri, pp. $218-225$.

Chandra, K. (1938). Instability of fluids heated from below. Proceedings of the Royal Society of London 164, pp. 231-242.

Chang, J., and Wetzel, P. J. (1991). Effects of spatial variations of soil moisture and vegetation on the evolution of a prestorm environment: a numerical case study. Monthly Weather Review 119 , pp. $1368-1390$.

Changnon, S. A. Jr (1978). Urban effects on severe local storms at St. Louis. Journal of Applied Meteorology 17, pp. 578-586.

Chaston, P. R. (2002). Weather maps, 2nd ed. Kearney, NE: Chaston Scientific. 
Chisholm, A. J., and Renick, J. H. (1972). The kinematics of multicell and supercell Alberta hailstorms. Research Council of Alberta Hail Studies Report No. 72-2, pp. 24-31.

Colquhoun, J. R., and Shepherd, D. J. (1989). An objective basis for forecasting tornado intensity. Weather and Forecasting 4, pp. 35-50.

Cooley, J. R. (1978). Cold air funnel clouds. Monthly Weather Review 106, pp. 1368-1372.

Court, A., and Griffiths, J. F. (1985). Thunderstorm climatology. In: Kessler, E. (ed.) Thunderstorm morphology and dynamics. Norman, OK: University of Oklahoma Press, pp. 9-40.

Davies, J. M. (1989). On the use of shear magnitude and hodographs in tornado forecasting Preprints. 12th Conference on Weather Forecasting and Analysis. American Meteorological Society, Monterey, California, pp. 219-224.

Davies, J. M., and Johns, R. H. (1993). Some wind and stability parameters associated with strong and violent tornadoes Part I: wind shear and helicity. In: Church, C. (ed.) Proceedings of Tornado Symposium III. Washington, DC: American Geophysical Union, pp. 573-582.

Davies-Jones, R. P. (1984). Streamwise vorticity: the origin of updraft rotation in supercell storms. Journal of the Atmospheric Sciences 41, pp. 2991-3006.

Davies-Jones, R. P., Burgess, D., and Foster, M. (1990). Test of helicity as a tornado forexast parameter Preprints. 16th Conference on Severe Local Storms. American Meteorological Society, Kananaskis Park, Alberta, pp. 588-592.

Davies-Jones, R. P., and Kessler, E. (1974). Tornadoes. In: Hess, W. (ed.) Weather and Climate Modification. New York, NY: Wiley-Interscience, pp. 552-595.

Djuric, D. (1994). Weather analysis. Englewood Cliffs, NJ: Prentice Hall.

Doswell, C. A. III (1982). Operational mesoanalysis. National Oceanic and Atmospheric Administration Technical Memorandum NWS NSSFC-5.

- (1986). The human element in weather forecasting. National Weather Digest 11, pp. 6-17.

Doswell, C. A. III, and Maddox, R. A. (1986). The role of diagnosis in weather forecasting Preprints. 11th Conference on Severe Local Storms. American Meteorological Society, Kansas City, Missouri, pp. 177-182.

Doswell, C. A. III, Moller, A. R., and Brooks, H. E. (1999). Storm spotting and public awareness since the first tornado forecasts of 1948. Weather and Forecasting 14, pp. 544-557.

Doswell, C. A. III, Moller, A. R., and Przybylinski, R. (1990). A unified set of conceptual models for variations on the supercell theme Preprints. 16th Conference on Severe Local Storms. American Meteorological Society, Kananaskis Park, Alberta, pp. 40-45.

Eagleman, J. R., and Lin, W. C. (1977). Severe thunderstorm internal structure from dual-Doppler radar measurements. Journal of Applied Meteorology 16, pp. 1036-1048.

Edwards, R., and Thompson, R. L. (2000). RUC-2 supercell proximity soundings Part II: an independent asessment of supercell forecast parameters Preprints. 20th Conference on Severe Local Storms. American Meteorological Society, Orlando, Florida.

Farrell, R. J., and Carlson, T. N. (1989). Evidence for the role of the lid and underunning in an outbreak of tornadic thunderstorms. Monthly Weather Review 117, pp. 857-871.

Fawbush, E. J., and Miller, R. C. (1953). A method for forecasting hailstone size at the earth's surface. Bulletin of the American Meteorological Society 34, pp. 235-244.

Fawbush, E. J., Miller, R. C., and Starrett, L. G. (1951). An empirical method of forecasting tornado development. Bulletin of the American Meteorological Society 32, pp. 1-9.

Fenn, A. J., et al. (2000). The development of phased-array radar technology. Lincoln Laboratory Journal 12, pp. 321-340.

Foote, G. B., and Frank, H. W. (1983). Case study of a hailstorm in Colorado Part III: airflow from triple-Doppler measurements. Journal of the Atmospheric Sciences 40, pp. 686-707.

Forbes, G. S., and Wakimoto, R. M. (1983). A concentrated outbreak of tornadoes, downbursts and microbursts, and implications regarding vortex classification. Monthly Weather Review 111, pp. $220-235$.

Foster, D. S. (1958). Thunderstorm gusts compared with computed downdraft speeds. Monthly Weather Review 86, pp. 91-94.

Fujita, T. T. (1978). Manual of downdraft identification for project. NIMROD SMRP Research Paper No. 156, University of Chicago.

- (1979). Objectives, operations, and results of Project NIMROD Preprints. 11th Conference on Severe Local Storms. American Meteorological Society, Kansas City, Missouri, pp. 259-266. 
(1981). Tornadoes and downbursts on the context of generalized planetary scales. Journal of the Atmospheric Sciences 38, pp. 1511-1534

Fujita, T. T., and Byers, H. R. (1977). Spearhead echo and downburst in the crash of an airliner. Monthly Weather Review 105, pp. 129-146.

Fujita, T. T., and Wakimoto, R. M. (1981). Five scales of airflow associated with a series of downbursts on 16 July 1980. Monthly Weather Review 109, pp. 1438-1456.

Galway, J. G. (1985). J. P. Finley: the first severe storms forecaster. Bulletin of the American Meteorological Society 66, pp. 1389-1395.

Garrett, A. J. (1982). A parameter study of interactions between convective clouds, the convective boundary layer, and a forested surface. Monthly Weather Review 110, pp. 1041-1059.

Graziano, T. M., and Carlson, T. N. (1989). A statistical evaluation of lid strength on deep convection. Weather and Forecasting 2, pp. 127-139.

Hane, C. E. (1986). Extratropical squall lines and rainbands. In: Ray, P. S. (ed.) Mesoscale meteorology and forecasting. Boston, MA: American Meteorological Society, pp. 359-389.

Harman, J. R. (1971). Tropospheric waves, jet streams, and United States weather patterns. Commission on College Geography Resources Paper No. 11, American Association of Geographers, Washington, DC.

Harnack, R. P., and Quinan, J. S. (1989). Association of jet streaks and vorticity advection patterns with severe thunderstorms in the northeastern United States. National Weather Digest 14, pp. 5-12.

Hart, J. A., and Korotky, W. D. (1991). The Sharp Workstation user's manual. Charleston, WV: National Oceanic and Atmospheric Administrations/National Weather Service Charleston West Virginia.

Hitchens, N. M., and Arnold, D. L. (2005). Middletown USA: perceptions of the severe weather threat. 8th Annual National Weather Association Severe Storms and Doppler Radar Conference, Des Moines, Iowa.

Holton, J. R. (1967). The diurnal boundary layer wind oscillation above sloping terrain. Tellus 19, pp. $199-205$.

-. (1992). An introduction to dynamic meteorology. San Diego, CA: Academic Press.

Johns, R. H. (1982). A synoptic climatology of northwest flow severe weather outbreaks Part I: nature and significance. Monthly Weather Review 110, pp. 1653-1663.

- (1993). Meteorological conditions associated with bow-echo development in convective storms. Weather and Forecasting 8, pp. 294-299.

Johns, R. H., and Doswell, C. A. III (1992). Severe local storms forecasting. Weather and Forecasting 7, pp. 588-612.

Johns, R. H., and Hirt, W. D. (1987). Derechos: widespread convectively induced windstorms. Weather and Forecasting 2, pp. 32-49.

Johns, R. H., Davies, J. M., and Leftwich, P. W. (1990). An examination of the relationship of the 0-2 km AGL 'positive' wind shear to potential buoyant energy in strong and violent tornado situations Preprints. 16th Conference on Severe Local Storms. American Meteorological Society, Kananaskis Park, Alberta, pp. 593-598.

Joint Doppler Operational Project Staff. (1979). Final report of the Joint Doppler Operational Project. National Oceanic and Atmospheric Administration Technical Memo ERL NSSL-86. National Severe Storms Laboratory, Norman, Oklahoma.

Kamburova, P. L., and Ludlam, F. H. (1966). Rainfall evaporation in thunderstorm downdrafts. Quarterly Journal of the Royal Meteorological Society 92, pp. 510-518.

Keen, C. S., and Lyons, W. A. (1978). Lake/land breeze circualtions on the western shore of Lake Michigan. Journal of Applied Meteorology 17, pp. 1843-1855.

Kelly, D. L., et al. (1978). An augmented tornado climatology. Monthly Weather Review 106, pp. $1172-1183$.

Klemp, J. B., and Weisman, M. L. (1983). The dependence of convective precipitation patterns on vertical wind shear Preprints. 21st Radar Meteorology Conference. American Meteorological Society, Edmonton, Alberta, pp. 44-49.

Kuo, Y. (2003). Mesoscale numerical weather prediction. Harold D. Orville Symposium. Institute of Atmospheric Sciences, South Dakota School of Mines and Technology, Rapid City, South Dakota, pp. 51-67. 
Lanicci, J. M., and Warner, T. T. (1991). A synoptic climatology of the elevated mixed layer inversion over the southern Great Plains in spring Part III: relationship to severe-storms climatology. Weather and Forecasting 6, pp. 214-226.

LaPenta, K. D., et al. (2005). A multiscale examination of the 31 May 1998 Mechanicville, New York, tornado. Weather and Forecasting 20, pp. 494-516.

Lazarus, S. M., and Droegemeier, K. K. (1990). The influence of helicity on the stability and morphology of numerically simulated storms Preprints. 16th Conference on Severe Local Storms. American Meteorological Society, Kananaskis Park, Alberta, pp. 269-274.

Lee, J. T., and Galway, J. G. (1956). Preliminary report on the relationship between the jet at the $200 \mathrm{mb}$ level and tornado occurrence. Bulletin of the American Meteorological Society 37, pp. 327-332.

P. (1958). The jet chart. Bulletin of the American Meteorological Society 39, pp. 217-223.

Leftwich, P. W. Jr (1990). On the use of helicity in operational assessment of severe local storm potential Preprints. 16th Conference on Severe Local Storms. American Meteorological Society, Kananaskis Park, Alberta, pp. 306-310.

Lemon, L. R., and Doswell, C. A. III (1979). Severe thunderstorm evolution and mesocyclone structure as related to tornadogenesis. Monthly Weather Review 107, pp. 1184-1197.

Ligda, M. G. H. (1951). Radar storm observations. In: Compendium of Meteorology, Boston, MA: AMS, pp. 1265-1282.

Lilly, D. K. (1986). The structure, energetics and propagation of rotating convective storms Part II: helicity and storm stabilization. Journal of the Atmospheric Sciences 43, pp. 126-140.

Lloyd, J. R. (1942). The development and trajectories of tornadoes Monthly Weather Review 70, pp. $65-75$.

Lyons, W. A. (1966). Some effects of Lake Michigan upon squall lines and summer convection. Great Lakes Research Division, University of Michigan, Publication No. 15.

Maddox, R. A., and Doswell, C. A. III (1982). An examination of jet stream configurations, $500 \mathrm{mb}$ vorticity advection and low-level thermal advection patterns during extended periods of intense convection. Monthly Weather Review 110, pp. 184-197.

Maddox, R. A., Hoxit, L. R., and Chappell, C. F. (1980). A study of tornadic thunderstorm interactions with thermal boundaries. Monthly Weather Review 108, pp. 322-336.

Mahfouf, J. F., and Richard, E. M. (1987). The influence of soil and vegetation on the development of mesoscale circualtions. Journal of Climate and Applied Meteorology 26, pp. 1483-1495.

Mahoney, W. P. III (1988). Gust front characteristics and the kinematics associated with interacting thunderstorm outflows. Monthly Weather Review 116, pp. 1474-1491.

Mahrer, Y., and Pielke, R. A. (1978). The meteorological effect of the changes in surface albedo and moisture. Israel Meteoroligcal Research Papers 2, pp. 55-70.

Mal, S., and Rao, Y. P. (1945). Effect of vertical acceleration on pressure during thunderstorms. Quarterly Journal of the Royal Meteorological Society 71, pp. 419-421.

Marwitz, J. D. (1972a). The structure and motion of severe hailstorms Part I: supercell storms. Journal of Applied Meteorology 11, pp. 166-179.

- (1972b). The structure and motion of severe hailstorms Part II: mutlicell storms. Journal of Applied Meteorology 11, pp. 180-188.

- (1972c). The structure and motion of severe hailstorms Part III: severely sheared storms. Journal of Applied Meteorology 11, pp. 189-201.

McCann, D. W. (1983). The enhanced-V, a satellite observable severe storm signature. Monthly Weather Review 111, pp. 887-894.

McCorcle, M. D. (1988). Simulation of surface-moisture effects on the Great Plains low-level jet. Monthly Weather Review 116, pp. 1705-1720.

Menzel, W. P., and Purdom, J. F. W. (1994). Introducing GOES-I: the first of a new generation of Geostationary Operational Environmental Satellites. Bulletin of the American Meteorological Society 75, pp. 757-781.

Miller, R. C. (1972). Notes on analysis of severe-storm forecasting procedures of the Air Force Global Weather Central. AFGWG Technical Report No. 200, Air Weather Service, Scott Air Force Base, IL, p. 190.

Miller, R. C., and Crisp, C. A. (1999). Events leading to establishment of the United States Air Force Severe Weather Warning Center in February 1951. Weather and Forecasting 14, pp. 500-506. 
Mills, E. (2005). Insurance in a climate of change. Science 309, pp. 1040-1044.

Moller, A. R. (1980). Mesoscale surface analysis of the 10 April 1979 tornadoes in Texas and Oklahoma Preprints. 8th Conference on Weather Forecasting and Analysis. American Meteorological Society, Denver, Colorado, pp. 36-43.

Moller, A. R., Doswell, C. A. III, and Przybylinski, R. (1990). High-precipitation supercells: a conceptual model and documentation Preprints. 16th Conference on Severe Local Storms. American Meteorological Society, Kananaskis Park, Alberta, pp. 52-57.

Moncrieff, M. W. (1978). The dynamical structure of two-dimensional steady convection in constant vertical shear. Quarterly Journal of the Royal Meteorological Society 104, pp. 543-567.

Moncrieff, M. W., and Green, J. S. A. (1972). The propagation and transfer properties of steady convective overturning in shear. Quarterly Journal of the Royal Meteorological Society 98, pp. 336-352.

Moncrieff, M. W., and Miller, M. J. (1976). The dynamics and simulation of tropical cumulonimbus and squall lines. Quarterly Journal of the Royal Meteorological Society 102, pp. 373-394.

Moore, J. T., VanKnowe, G. E., and Molinaro, R. C. (1990). A comparison of vertical motion approximations under varying jet streak curvatures Preprints. 16th Conference on Severe Local Storms. American Meteorological Society, Kananaskis Park, Alberta, pp. 52-57.

National Science and Technology Council. (2000). Effective disaster warnings. Report by the Working Group on Natural Disaster Information Systems Subcommittee on Natural Disaster Reduction, Washington, DC.

Ookouchi, Y., et al. (1984). Evaluation of soil moisture effects on the generation and modification of mesoscale circualtions. Monthly Weather Review 112, pp. 2281-2292.

Orlanski, I. (1975). A rational subdivision of scales for atmospheric processes. Bulletin of the American Meteorological Society 56, pp. 527-530.

Orton, R. (1970). Tornaodes associated with Hurricane Beulah on September 19-23, 1967. Monthly Weather Review 98, pp. 541-547.

Ostby, F. P. (1999). Improved accuracy in severe storm forecasting by the severe local storms unit during the last 25 years: then versus now. Weather and Forecasting 14, pp. 526-543.

Pearson, J. E. (1958). The influence of lakes and urban areas on radar observed precipitation echoes. Bulletin of the American Meteorological Society 39, pp. 79-82.

Peppler, R. A. (1988). A review of static stability indices and related thermodynamic parameters. Illinois State Water Survey Miscellaneous Publication 104, p. 87.

Peppler, R. A., and Lamb, P. J. (1989). Tropospheric static stability and central North American growing season rainfall. Monthly Weather Review 117, pp. 1156-1180.

Phillips, A. C., and Walker, G. T. (1932). The forms of stratified clouds. Quarterly Journal of the Royal Meteorological Society 58, p. 23.

Physick, W., and Tapper, N. J. (1990). Numerical study of circulations induced by a dry salt lake. Monthly Weather Review 118, pp. 1029-1042.

Pielke, R. A. (2002). Mesometeorology, 2nd ed. San Diego, CA: Academic Press.

Pielke, R. A., and Segal, M. (1986). Mesoscale circulations forced by differential terrain heating. In: Ray, P. S. (ed.) Mesoscale meteorology and forecasting. Boston, MA: American Meteorological Society, pp. 516-548.

Pielke, R. A., and Zeng, X. (1989). Influence on severe storm development of irrigated land. National Weather Digest 14, pp. 16-17.

Pinty, J. P., et al. (1989). An investigation of mesoscale flows induced by vegetation in homogeneities using an evapotranspiration model calibrated against the Hapex-Mobilhy data. Journal of Applied Meteorology 28, pp. 976-992.

Pitchford, K. L., and London, J. (1962). Low-level jet as related to nocturnal thunderstorms over the Midwest United States. Journal of Applied Meteorology 1, pp. 43-47.

Przybylinski, R. W. (1995). The bow echo: Observations, numerical simulations, and severe weather detection methods. Weather and Forecasting 10, pp. 203-218.

Purdom, J. F. W. (1972). Mesohighs and satellite imagery. Monthly Weather Review 101, pp. 180-181.

- (1976). Some uses of high-resolution GOES imagery in the mesoscale forecasting of convection and its behavior. Monthly Weather Review 104, pp. 1474-1483.

Rabin, R. M., et al. (1990). Observed effects of landscape variability on convective clouds. Bulletin of the American Meteorological Society 71, pp. 272-280. 
Rasmussen, E. N. (2003). Refined supercell and tornado forecast parameters. Weather and Forecasting 18, pp. 530-535.

Ray, P. (1990). Convective dynamics. In: Atlas, D. (ed.) Radar in meteorology. Boston, MA: American Meteorological Society, pp. 348-400.

Read, W. L. (1987). Observed microbursts in the National Weather Service Southern Region during 1986 - four case studies. National Oceanic and Atmospheric Administration Technical Memorandum NWS SR-121, pp. 10-34.

Reynolds, D. W. (1980). Observations of damaging hailstorms from geosynchronous satellite digital data. Monthly Weather Review 108, pp. 337-348.

Riehl, H. (1952). Forecasting in the middle latitudes. Metetorological Monograph No. 5. Boston, MA: American Meteorological Society.

Riley, P. A., and Colquhoun, J. R. (1994). The environment of United States tornadoes and relationships with tornado intensity. 1st National Australian Meteoroligcal and Oceanographic Society Conference, University of Adelaide, p. 68.

Rotunno, R. (1981). On the evolution of thunderstorm rotation. Monthly Weather Review 109, pp. $171-180$.

Schmidt, J. M., and Cotton, W. R. (1989). A High Plains squall line associated with severe surface winds. Journal of the Atmospheric Sciences 46, pp. 281-302.

Schreiber, W. E. (1986). Case studies of thunderstorms initiated by radar-observed convergence lines. Monthly Weather Review 114, pp. 2256-2266.

Scofield, R. A., and Purdom, J. F. W. (1986). The use of satellite data for mesoscale analyses and forecasting applications. In: Ray, P. S. (ed.) Mesoscale meteorology and forecasting. Boston, MA: American Meteorological Society, pp. 359-389.

Segal, M., and Arritt, R. W. (1992). Non-classical mesoscale circulations caused by surface sensible heat-flux gradients. Bulletin of the American Meteorological Society 73, pp. 1593-1604.

Segal, M., et al. (1986). Evaluation of cloud shading effects on the generation and modification of mesoscale circulations. Monthly Weather Review 114, pp. 1201-1212.

- (1988). Evaluation of vegetation effects on the generation and modification of mesoscale circulations. Journal of the Atmospheric Sciences 45, pp. 2268-2292.

Skupniewicz, C. W., Glendening, J. W., and Kadama, R. F. (1991). Boundary layer transition across a stratocumulus cloud edge in a coastal zone. Monthly Weather Review 119, pp. 2337-2357.

Smull, B. F., and Houze, R. A. (1987). Rear inflow in squall lines with trailing stratiform precipitation. Monthly Weather Review 115, pp. 2869-2889.

Srivasrava, R. C. (1985). A simple model of evaporatively driven downdraft: Application to microburst downdraft. Journal of the Atmospheric Sciences 42, pp. 1004-1023.

Stull, R. B. (1988). An introduction to boundary layer meteorology. Norwell, MA: Kluwer Academic.

Tang, T., and Bringi, V. N. (2003). An analysis of dual-polarized radar measurables for rainfall measurement. 31st International Conference on Radar Meteorology. American Meteorological Society, Seattle, Washington.

Tegtmeier, S. A. (1974). The role of the surface, sub-synoptic low pressure system in severe weather forecasting. Unpublished MS Thesis. Department of Meteorology, University of Oklahoma.

Tessendorf, S. A., and Trapp, R. J. (2000). On the climatological distribution of tornadoes within quasi-linear convective systems Preprints. 20th Conference on Severe Local Storms. American Meteorological Society, Orlando, Florida, pp. 134-137.

Thompson, R. L., Mead, C. M., and Edwards, R. (2004). Effective bulk shear in supercell thunderstorm environments Preprints. 22nd Conference on Severe Local Storms. American Meteorological Society, Hyannis, Massachusetts.

Trapp, R. J. (1999). Observations of non-tornadic low-level mesocyclones and attendant tornadogenesis failure during VORTEX. Monthly Weather Review 127, pp. 1693-1705.

Uccellini, L. W. (1975). A case study of gravity wave initiation of severe convective storms. Monthly Weather Review 103, pp. 497-513.

Uccellini, L. W., and Kocin, P. J. (1987). The interaction of jet streak circualtions during heavy snow events along the east coast of the United States. Weather and Forecasting 2, pp. 289-308.

Vinnichenko, N. K. (1970). The kinetic energy spectrum in the free atmosphere -1 second to 5 years. Tellus 22, pp. 158-166. 
Wakimoto, R. M., and Wilson, J. W. (1989). Non-supercell tornadoes. Monthly Weather Review 117, pp. 1113-1140.

Weaver, J. F., Purdom, J. F. W., and Szoke, E. J. (1994). Some mesoscale aspects of the 6 June 1990 Limon, Colorado, tornado case. Weather and Forecasting 9, pp. 45-61.

Weisman, M. L., and Davis, C. (1998). Mechanisms for the generation of mesoscale vortices within quasi-linear convective systems. Journal of the Atmospheric Sciences 55, pp. 2603-2622.

Weisman, M. L., and Klemp, J. B. (1982). The dependence of numerically simulated convective storms on vertical wind shear and buoyancy. Monthly Weather Review 100, pp. 504-520.

(1984). The structure and classification of numerically convective storms in directionally varying wind shears. Monthly Weather Review 112, pp. 2479-2498.

- (1986). Characteristics of isolated convective storms. In: Ray, P. S. (ed.) Mesoscale meteorology and forecasting. Boston, MA: American Meteorological Society, pp. 331-389.

Wexler, H. (1961). A boundary layer interpretation of the low-level jet. Tellus 13, pp. 368-378.

Wheatley, D. M., and Trapp, R. J. (2006). Numerical simulation of quasi-linear convective systems in heterogeneous mesoscale environments Preprints. 23rd Conference on Severe Local Storms. American Meteorological Society, St Louis, Missouri.

Wilson, J. W., and Schreiber, W. E. (1986). Initiation of convective storms at radar-observed boundary-layer convergence lines. Monthly Weather Review 114, pp. 2516-2536.

WMO (2004). Weather, climate, water and sustainable development. Geneva, Switzerland: World Meteorological Organization.

Zipser, K. A. (1982). Use of a conceptual model of the life cycle of mesoscale convective systems to improve very-short-range forecasts. In: Browning, K. (ed.) Nowcasting. San Diego, CA: Academic Press, pp. 191-204. 